\title{
Histological Study of the Caffeine Effect on Intact Gastric Mucosa and Induced Gastric Ulcer in Adult Male Albino Rats
}

\author{
Original \\ Article Asmaa Hassan Abd-Elhamid, Mona Abd-Elrahman Salem, Shadia Mohamed \\ Mahmoud and Mona Mohamed Abd-Elgalil
}

Department of Histology, Faculty of Medicine (Girls), Al-Azhar University, Cairo, Egypt

\begin{abstract}
Introduction: Gastric ulcer is a serious health problem of worldwide concern.Caffeine is affirmed globally as a safe dietary element as a result of its high antioxidant content.

Aim of the Work: To assess the cytoprotective impact of caffeine on the intact gastric mucosa and aspirin-induced gastric ulcer in adult male albino rats.

Materials and Methods: Forty-two adult male albino rats were divided into four groups. Group I (control group). Group II (caffeine group), received aqueous caffeine $(300 \mathrm{mg} / \mathrm{kg} /$ day) by gastric tube. Group III, overnight fasted rats received aspirin solution $(200 \mathrm{mg} / \mathrm{kg} /$ day) orally for 5 consecutive days, then rats were further subdivided equally into: Subgroup IIIa (gastric ulcer group), sacrificed six hours after the last aspirin dose, subgroup IIIb, left without treatment for 4 weeks and subgroup IIIc received caffeine orally for 4 weeks. Group IV (caffeine prophylactic group) before ulcer induction. Serum was maintained for antioxidants activity assay; total antioxidant capacity (TAC), prostaglandin (PGE2) and tumour necrotic factor-alpha (TNF- $\alpha$ ).Specimens of stomach body were processed for light and electron microscopic studies. Morphometric and statistical analysis was done.

Results: Light microscopic study of the gastric ulcer group depicted deep erosion, damage of parietal and chief cells with vacuolated cytoplasm and pyknotic nuclei, congested blood vessels and aggregated mononuclear inflammatory cells that were supported by a significant increase of (TNF- $\alpha$ ) expression coupled to a significant decrease in PGE2 and TAC levels and a significant reduction of Periodic-Acid-Schiff reaction coupled to a significant increase in area percentage of collagen fibers upon aspirin administration. The ultrastructural assessment confirmed these distortions. Whereas, caffeine prophylactic and treated groups revealed greater improvement in the histological changes depicted previously.

Conclusion:Caffeine has protective impacts on the intact gastric mucosa. Additionally, it alleviated aspirin-induced gastric mucosal lesions in adult male albino rats that might be related to its high antioxidant content.
\end{abstract}

Received: 07 May 2020, Accepted: 07 June 2020

Key Words: Antioxidant; aspirin; caffeine; gastric ulcer; tumour necrosis factor- $\alpha$.

Corresponding Author: Asmaa Hassan Abd-Elhamid, MSc, Department of Histology, Fuculty of Medicine (Girls), Al Azhar University, Nasr city, Cairo, Tel.: +202 25519437, E-mail: asma_arida@yahoo.com

ISSN: 1110-0559, Vol. 44, No.1

\section{INTRODUCTION}

Gastric ulcer is the most benign injuries in the stomach and remains a frequent clinical problem in our environment predominantly affecting all age and gender of people and has a significant global impact on health economics and the quality of patient's life $\mathrm{f}^{[1]}$.

Gastric ulcer is complicated by bleeding, perforation and erosion of the gastric mucosa caused by the disruption of the gastric mucosal defence systems due to imbalance between aggressive causes (non-steroidal antiinflammatory drugs (NSAIDs), smoking, stress, alcohol, bile salts, acid, pepsin and Helicobacter pylori infection) and defensive factors (mucin, bicarbonate, prostaglandin, nitric oxide, adequate mucosal blood flow, growth factors and ability to epithelial renewal ${ }^{[2]}$.

Aspirin is the most frequently prescribed analgesic, antipyretic and anti-inflammatory NSAID and is also used to prevent cardiovascular thrombotic diseases. Despite its therapeutic benefits, its utilization in a wide variety of clinical conditions has been restricted by its gastric ulcerinducing effects in both human and animals ${ }^{[3,4]}$.

The pathogenesis of aspirin-induced gastric ulcer includes blocking certain prostaglandins (PGs) synthesis through the inhibition of cyclooxygenase enzymes, debilitating the defensive gastric mucosal barrier, decreasing mucosal blood flow, and altering the microvascular structures which lead to epithelial damage, the release of proinflammatory mediators and free radicals as well as increase leukocyte infiltration and decrease antioxidant enzymes predisposing to ulcer ${ }^{[5]}$.

Caffeine, the common name for 1, 3, 7-trimethyl xanthine, is a naturally occurring alkaloid belonging to methylxanthines group and it is one of the most widely consumed psychoactive beverage in the world ${ }^{[6,7]}$. It is commonly used as dietary supplements in soft drinks, 
energy drinks as well as in an assortment of medical prescriptions such as some pain reliever formulations ${ }^{[8]}$.

Chlorogenic acid is the main phenolic compounds present in caffeine that contributes to the flavour and aroma characteristic of the beverage as well as has antioxidant activity ${ }^{[9]}$

Generally, many controversial studies thought the probable association of gastro-oesophageal reflux and gastric ulcer with coffee consumption due to gastrin release and gastric acid secretion induced by coffee containing caffeine ${ }^{[10]}$. However, one of the most recent studies reported the potential gastroprotective activity of caffeine because of its antioxidant effect and antagonizing the propagation of the oxidative process responsible for the damage of gastric mucosa ${ }^{[9]}$.

So this study aimed to analyze the cytoprotective capacity of caffeine on the intact gastric mucosa and the aspirin-induced ulcerative lesion in the stomach of adult male albino rats.

\section{MATERIALS AND METHODS}

\section{Animals}

Forty-two adult male Rattus norvogicus albino rats, age $12-16$ weeks, weighing $150 \pm 20 \mathrm{~g}$ were used in the present study. Rats were purchased from Helwan breeding farm, Helwan, Egypt. Animals were settled in conventional clean properly ventilated stainless steel meshed cages at a room temperature of $25 \pm 2^{\circ} \mathrm{C}$, the humidity of $(54 \pm 5 \%)$ and alternating light/dark cycles under normal hygienic conditions at the animal house, Faculty of Medicine (Girls), Al-Azhar University, Cairo. Rats were acclimated for one week before the beginning of the experiment. They were allowed free access to water and rat chow throughout the experiment. All the ethical protocols for animal treatment were followed according to the Research Ethics Committee (FMG-IRB), Faculty of Medicine (Girls), Al-Azhar University.

\section{Drugs and chemicals}

- Aspirin: A commercially available formulation of acetylsalicylic acid (ASA) was used (Aspirin protect enteric-coated tablets $100 \mathrm{mg}$; Bayer Bitterfeld Gmbh, Germany).

- Caffeine (1, 3, 7 trimethyl xanthine): A bottle containing $100 \mathrm{gm}$ of concentrated powder, provided from Sigma-Aldrich chemical company (CAS Number 58-08-2), St Louis, Missouri. USA. It was purchased from the Egyptian International Center for Import, Nasr City, Cairo, Egypt.

Aqueous caffeine preparation: caffeine powder was dissolved in distilled water (DW), $1 \mathrm{ml}$ of freshly prepared aqueous caffeine $(45 \mathrm{mg} / \mathrm{ml})$ was given daily by oro-gastric tube at a dose of $300 \mathrm{mg} / \mathrm{kg}^{[11]}$.

\section{Induction of gastric ulcer}

Aspirin was dissolved in 1\% carboxymethyl cellulose $(\mathrm{CMC})$ and the gastric ulcer was induced by administering overnight fasted rats aspirin solution $(30 \mathrm{mg} / \mathrm{ml})$ by orogastric tube in the early morning at a daily dose of 200 $\mathrm{mg} / \mathrm{kg}$ for 5 consecutive days ${ }^{[4]}$.

\section{Experimental design}

Rats were divided into four main groups:

- Group I (control group): 12 adult male rats were further subdivided equally into two subgroups:

- Subgroup IA: each rat was given $1 \mathrm{ml}$ of distilled water once daily by gastric gavage for 4 weeks.

- Subgroup IB: each overnight fasted rat received $1 \mathrm{ml}$ of $1 \% \mathrm{CMC}$ (Aspirin vehicle) orally once daily for 5 consecutive days.

- Group II (Caffeine group): six overnight fasted rats received $1 \mathrm{ml}$ of aqueous caffeine solution $(45 \mathrm{mg} / \mathrm{ml})$ daily in the early morning by a gastric tube for 4 weeks.

- Group III: eighteen overnight fasted rats received $1 \mathrm{ml}$ of aspirin solution $(30 \mathrm{mg} / \mathrm{ml})$ by gastric tube in the early morning for 5 consecutive days, and then rats were further subdivided equally into three subgroups:

- Subgroup IIIa (Gastric ulcer group), rats were sacrificed six hours after the last aspirin dose.

- Subgroup IIIb (Untreated group), rats with aspirin-induced gastric ulcer were left spontaneously without any treatment till the end of the experiment (4 weeks) and then they were sacrificed.

- Subgroup IIIc (Caffeine-treated group) received aqueous caffeine orally by the same dose and duration as group II along with basal diet daily for 4 weeks following ulcer induction and then they were sacrificed.

- Group IV (prophylactic group): six overnight fasted rats received freshly prepared aqueous caffeine by the same dose and duration as group II. After the 4th week, the gastric ulcer was induced using aspirin solution by the same dose and duration as group III, and then they were sacrificed six hours after the last aspirin dose.

- The animals of all groups were weighed individually at the beginning of the experiment and the end just before collecting samples. 
At the end of the experiment, the overnight fasted rats were anaesthetized by ether inhalation, blood samples were withdrawn from retro-orbital sinuses by capillary tubes, centrifuged at 3000 round per minute to separate the serum that was maintained in a freezer at $-80^{\circ} \mathrm{C}$ until further analyses for antioxidants activity assay ${ }^{[12]}$; total antioxidant capacity (TAC), prostaglandin (PGE2) and tumour necrotic factor-alpha (TNF- $\alpha$ ). TAC was measured using a colourimetric method (Biodiagnostic Company, Egypt $)^{[13]}$. PGE2 concentrations were investigated using the PGE2 enzyme-linked immunosorbent assay (ELISA) Kit (DRG International, Inc., USA) ${ }^{[14]}$. The levels of tumour necrotic factor-alpha (TNF- $\alpha$ ) was also determined using a rat-specific, commercially available enzymelinked immunosorbent assay kit (BioSource International Inc., California, USA) according to the manufacturer's instructions ${ }^{[15]}$ at El Nour Global Lab, Cairo, Egypt. Results of PGE2 and TNF- $\alpha$ are expressed as $\mathrm{pg} / \mathrm{ml}$, while those of $\mathrm{TAC}$ are expressed as $\mathrm{mM} / \mathrm{L}$

The stomach from each anaesthetized rat was immediately dissected out, opened along the greater curvature, washed gently in $10 \%$ formalin to remove any gastric contents, stretched on a segment of cork on glass plates with mucosal surface up for macroscopic examination. The inner surface had been scanned, photographed to assess the extent of gastric lesions ${ }^{[4]}$.

\section{Histological Examination}

\section{Light Microscopic Examination}

Specimens from the body of the stomach were fixed in $10 \%$ formalin 48 hours, dehydrated in ascending grades of ethyl alcohol, cleared in xylene, impregnated and embedded in molten paraffin wax, sectioned with the rotatory microtome at $5 \mu \mathrm{m}$ thickness, then mounted on clean glass slides and stained with Hematoxylin and Eosin (H\&E) stain for studying the general histological structure, Mallory's Trichrome stain for demonstration of collagen fibers and Periodic Acid-Schiff (PAS) technique for demonstration of mucous substances ${ }^{[16]}$

\section{Transmission Electron Microscopic Examination (TEM)}

Small pieces of stomach specimens, approximately 0.5 $\mathrm{mm}$ thickness were immediately fixed in $4 \%$ phosphatebuffered glutaraldehyde $(0.1 \mathrm{M}, \mathrm{pH} 7.3)$, post-fixed with $1 \%$ phosphate-buffered osmium tetroxide. Afterwards dehydrated in ascending grades of ethanol and then processed according to Hayat ${ }^{[17]}$. Semithin sections $(1 \mu \mathrm{m}$ thick) were stained with toluidine blue and examined by light microscope for proper orientation. The ultrathin sections $(50-60 \mathrm{~nm})$ were stained with uranyl acetate and lead citrate, examined and photographed by JEOL 1010 transmission electron microscope (Jeol; Tokyo, Japan), at the Regional Center for Mycology and Biotechnology (RCMB), AL-Azhar University.

\section{Morphometric Measurements and Statistical Analysis}

All sections were examined by Leica light microscope MDLSD coupled to a Leica digital camera transferred to the screen using a computerized image analyzer Leica Q500 MC program (Leica Microsystems Ltd, Cambridge, UK). The data were calibrated automatically to convert the measurement units (pixels) produced by the image analyzer program into actual micrometer units. Ten different nonoverlapping randomly selected fields from a slide of each rat in all different experimental groups were examined to quantitatively evaluate the following:

a. Parietal cells count in H\&E stained section at a magnification of 400 .

b. Mean area percentage of PAS-positive histochemical reaction in PAS stained sections at a magnification of 200 .

c. Mean area percentage of collagen fibers in the lamina propria of mucosa between gastric glands and submucosa in Mallory's trichrome stained sections at a magnification of 200 .

All histomorphometric measurements were carried out at Pathology department, Faculty of dentistry (Girls), Al-Azhar University.

All statistical data were analyzed using Statistical Program for Social Science, version 20 (SPSS Inc., Chicago, Illinois, USA). Statistical significance was determined by one-way analysis of variance for differences between the means of different groups. Further analysis was carried out using the post hoc test to compare the parameters in the different groups with each other. All data were expressed as mean \pm Standard Deviation (mean \pm SD) and a probability of $P<0.05$ was considered statistically significant ${ }^{[18]}$.

\section{RESULTS}

\section{Gross appearance}

Macroscopic examinations of the stomach of the control (GI) and caffeine groups (GII) revealed normal intact gastric mucosa that appeared smooth, glistening and pink in colour with prominent rugae (Figures 1a, 1b). Apparent injuries were detected in gastric ulcer group (GIIIa) in the form of dark red hyperemic patches and streaks scattered throughout the gastric mucosa (Figure 1c). In the untreated group (GIIIb), many hyperemic streaks appeared scattered throughout the mucosa (Figure 1d). While, marked improvement was detected in the treated group (GIIIc) despite only a few prominent dark red pinpoint spots scattered within the gastric mucosa (Figure 1e). Finally, caffeine prophylactic group (GIV) showed normal gastric mucosa with prominent gastric rugae closely similar to the control group (Figure 1f). 


\section{Histological results}

In the present study, examination of the structure of body of the stomach of rats of group I (control group) and group II (caffeine group) revealed nearly similar histological structure in all different histological methods.

\section{a. Light microscopic results}

\section{Haematoxylin and eosin-stained sections results}

Histological examination of H\&E stained sections of stomach of group I (control) and group II (caffeine) revealed normal histoarchitecture of the gastric mucosa. It composed of epithelium that was interrupted by short narrow gastric pits and lamina propria which was occupied by the long tightly packed simple tubular or branched tubular gastric glands laying perpendicular to the surface and extended down to the muscularis mucosa. The gastric glands were lined by simple columnar epithelium and were subdivided into isthmus, neck and base (Figures 2a, 2b). Gastric glands were. Surface lining cells in the isthmus were tall columnar mucous secreting cell with pale cytoplasm and basal oval vesicular nuclei. Neck region was lined by low columnar mucous neck cells with basal flattened nuclei and pale foamy cytoplasm interspersed with parietal cells (Figures 2c, 2d). The neck and base regions of the gastric glands were lined mostly by pyramidal to polyhedral parietal cells with deep acidophilic cytoplasm and central rounded vesicular nuclei. Peptic or chief cells were mainly located at the bases of the gastric glands, they appeared low columnar with basophilic cytoplasm and basally situated spherical nuclei (Figures 2e, 2f).

Examination of H\&E stained sections of the gastric ulcer group (GIIIa) showed multifocal severe mucosal damage in the form of deep gastric ulcers and sloughing epithelium with distortion of the glandular histoarchitecture. The ulcer base contained desquamated cells, acidophilic tissue remnants and cellular debris (Figure 3a). The desquamated cells, surface epithelial cells as well as mucous neck cells appeared pyknotic, shrunken with deeply stained acidophilic cytoplasm and small hyperchromatic and pleomorphic nuclei (Figure 3b). Parietal cells and chief cells appeared vacuolated with darkly stained small nuclei despite that, some of the chief cells appeared deep basophilic with darkly stained nuclei (Figure 3c). Congested blood vessels along with diffuse inflammatory cell infiltrations were observed in the lamina propria between the damaged gastric glands (Figures 3a, 3c).

The untreated group (GIIIb) revealed partial healing of the superficial part of the gatric ulcer with regularly arranged intact gastric glands but deeper part was still unhealed and showed detached cells. Nearly normal parietal and chief cells, despite that, few parietal cells appeared vacuolated. Congested dilated blood vessels in the lamina propria between gastric glands could also be detected (Figures $4 \mathrm{a}-4 \mathrm{c}$ ).
The treated group (GIIIc) showed marked improvement in the glandular architecture of the gastric mucosa comparable with that of the control group (Figure 5a). Surface epithelial cells and mucous neck cells were more or less similar to the control group (Figure 5b). Parietal and chief cells distributed throughout the bases of the glands appeared nearly normal. Congested blood vessels, few extravasated red blood corpuscles (RBCs) and inflammatory cell infiltrations in the lamina propria could be also observed (Figures 5b, 5c).

Caffeine ameliorated the destructive effect of aspirin on the gastric mucosa in the prophylactic group (GIV) as evident in $\mathrm{H} \& \mathrm{E}$ stained sections, where the structure of the gastric mucosa was nearly comparable to the control group. The gastric glands were regularly arranged with narrow pits (Figure 6a). Closely packed surface columnar mucous cells, mucous neck cells and some parietal cells line the apical parts of the gastric glands (Figure 6b). Chief and parietal cells lined the bases of the glands were closely similar to those of the control. However, inflammatory cells infiltration was observed in the lamina propria between the gastric glands (Figure 6c).

\section{Periodic acid Schiff (PAS) stained sections results}

Control (GI) and caffeine (GII) groups revealed continuous strong PAS-positive magenta red mucous film covered the mucosal surface of the stomach, down to pits, isthmus and neck regions. While, weak PAS-positive reaction appeared at the base regions of the gastric glands (Figures 7a, 7b). Gastric ulcer (GIIIa) and the untreated (GIIIb) groups revealed a focal loss of PAS reaction over the eroded surface epithelium, and complete loss of the PAS reaction at the ulcerated regions, despite preservation of PAS-positive reaction in the isthmus and neck regions yet it was less prominent than the control group (Figures 7c,7d). The treated group (GIIIc) revealed strong PAS-positive reaction in the form of a magenta mucus film at the healed regions nearly similar to the control group (Figure 7e). While, PAS reaction within the gastric mucosa in the prophylactic group (IV) appeared closely as the same as the control (Figure 7f).

\section{Mallory's Trichrome staining}

Control (GI) and caffeine (GII) group revealed fine dispersion of few thin collagen fibers extended in the thin lamina propria between gastric glands and the submucosa. (Figures 8a,8b). Examination of gastric ulcer group (GIIIa) and the untreated group (GIIIb) revealed an increase in the distribution of the collagen fibers in the lamina propria between the distorted gastric glands (Figure 8c) and the submucosa (Figure 8d) compared to the control group. While collagen fibers distribution in the lamina propria between gastric glands in the treated group (GIIIc) (Figure 8e) and in the prophylactic group (GIV) (Figure $8 \mathrm{f}$ ) was closely similar to the control group.

\section{b. Electron microscopic results}

Electron microscopic examination of the gastric mucosa of the control group (GI) and caffeine group 
(GII) showed large pyramidal parietal cells with basal rounded euchromatic nuclei. The cytoplasm revealed deep intracellular canaliculi lined by numerous long microvilli, prominent tubulovesicular structures and many rounded to ovoid mitochondria Figures 9a, 9b). Chief cells contained large basal rounded euchromatic nuclei with prominent nucleoli. The cytoplasm was rich in well developed closely packed cisternae of rough endoplasmic reticulum, scattered mitochondria and numerous apical variable-sized electrondense apical zymogen granules (Figures10a, 10b).

Meanwhile, Electron microscopic examination of the gastric mucosa of the ulcer group (GIIIa) revealed abnormal features of the parietal cells in the form of shrunken pyknotic nuclei with irregular outline and dilated perinuclear cisternae. The cytoplasm was filled with vacuoles and dilated distorted intracellular canaliculi with disrupted microvilli (Figure 11a). The chief cells showed shrunken pyknotic nucleus, with condensed heterochromatin, dilated cisternae of rough endoplasmic reticulum, dilated Golgi saccules and numerous large apical electron-dense zymogen granules (Figures 11b, 11c).

Electron microscopic examination of the gastric mucosa from the untreated group (GIIIb) showed parietal cells with wide dilated intracellular canaliculi lined by damaged microvilli. The cytoplasm contained many tubulovesicular structures and swollen electron-dense mitochondria (Figure 12a). Chief cells revealed shrunken irregular electron-dense nuclei with condensed heterochromatin and some dilated cisternae of rough endoplasmic reticulum, dilated Golgi saccules, degenerated mitochondria and variable-sized electron-dense zymogen secretory granules. Enteroendocrine cells revealed many degenerated granules in its cytoplasm (Figure 12b).

Electron microscopic examination of the treated group (GIIIc), showed some improvement in the ultrastructural changes of the glandular cells, where the parietal cells looked normal, the intracellular canaliculi lined by intact microvilli. Many rounded to ovoid electron-dense mitochondria could be also detected (Figure 13a). Normal chief cells contained euchromatic nuclei with the regular nuclear envelope, normal mitochondria. Slight dilatation of rough endoplasmic reticulum could be observed (Figure 13b).

Electron microscopic examination of the gastric mucosa of the prophylactic group (GIV) showed normal parietal cell with rounded euchromatic nuclei. The cytoplasm was filled with rounded to ovoid electron-dense mitochondria, intracellular canaliculi lined by microvilli and tubulovesicular system. Part of enteroendocrine cells appeared with small electron-dense secretory granules (Figure 14a). Moreover, chief cells were nearly more or less as the control group. They have rounded euchromatic nuclei with prominent nucleoli. The cytoplasm showed multiple variable-sized electron-dense zymogen granules, regular parallel cisternae of rough endoplasmic reticulum and well developed Golgi apparatus (Figure 14b).

\section{c. Morphometric measurements and statistical results}

The mean values of initial body weight among rats of all experimental groups were nearly similar with no statistically significant difference $(P>0.05)$. At the end of the experiment, the least recorded mean of final body weight was among the untreated group (GIIIc), followed by those of (GIIIa, GIIIb) as compared to the control rats. While, the highest mean value was recorded in the caffeine group (GII), followed by the prophylactic group (GIV) and the treated group (GIIIc) respectively, on comparable to the aspirin administrated groups. All these values were of statistically significant difference $(P<0.05)$ (Table 1$)$.

Serum analyses for antioxidants activity assay among rats of all experimental groups were illustrated in the (Table 2). The statistical comparison between control groups (IA, IB) revealed no significant difference among them $(p>0.05)$. The least recorded mean values of total antioxidant capacity (TAC) and prostaglandin (PGE2) were among the aspirin-induced gastric ulcer groups (GIIIa, GIIIb) respectively coupled with a significant increase in TNF- $\alpha$ as compared to the control rats $(P<0.05)$. Inversely, caffeine improved all these parameters as demonstrated by a significant increase in TAC, PGE2 coupled with the significant decrease in TNF- $\alpha$ when compared to aspirin administered groups $(P<0.05)$. The best-recorded data was among GII, then GIV and finally GIIIc. However, improvement in the all measured parameters could not reach to the control values as there was a significant difference when compared to the control groups $(P<0.05)$.

As regarding the histomorphometric analysis, it was found that the statistical comparison between control group (GI) and caffeine group (GII) revealed no significant difference among them $(p>0.05)$.

\section{a - Counting of parietal cell in the gastric glands among all rats of the experimental groups}

The highest recorded mean value was among the gastric ulcer groups (GIIIa, GIIIb) as compared to the control rats. While, the least mean value was among the prophylactic group (GIV) and the treated group (GIIIa) respectively on comparison to the aspirin administrated groups with a statistically significant difference $(P<0.05)$. However, the reduction in the number of parietal cells in (GIV, GIIIc) could not reach to the control values as there were significant differences when compared to the control groups $(P<0.05)$ (Table 3 and Histogram 1$)$.

\section{$b$ - The mean area percentage of PAS-positive reaction in the gastric glands among rats of the experimental groups}

It was observed that the least mean value in the mean area $\%$ of PAS reaction was recorded among the gastric ulcer groups (GIIIa, GIIIb) as compared to the control rats. while the highest mean value was recorded among the prophylactic group (GIV) followed by the treated 
group (GIIIc) on comparison to the gastric ulcer groups with a statistically significant difference $(P<0.05)$. The mean area percentage of PAS reaction among the group (GIIIc) was further lower versus the control group. This reduction was statistically of significant value $(P<0.05)$ (Table 4 and Histogram 2).

\section{c-Collagen area percentage in the lamina propria and the submucosa of the stomach among all rats of the experimental groups}

Image analysis revealed that the highest recorded mean value of area $\%$ of collagen fibers was among the gastric ulcer groups (GIIIb, GIIIa) respectively compared to control groups. While the least mean values were recorded among the group (GIV\& GIIIc) compared to the gastric ulcer groups. All these values were of statistically significant difference $(P<0.05)$. The mean value in GIIIc was further higher than the control with a statistically significant difference $(P<0.05)$ (Table 5 and Histogram 3)
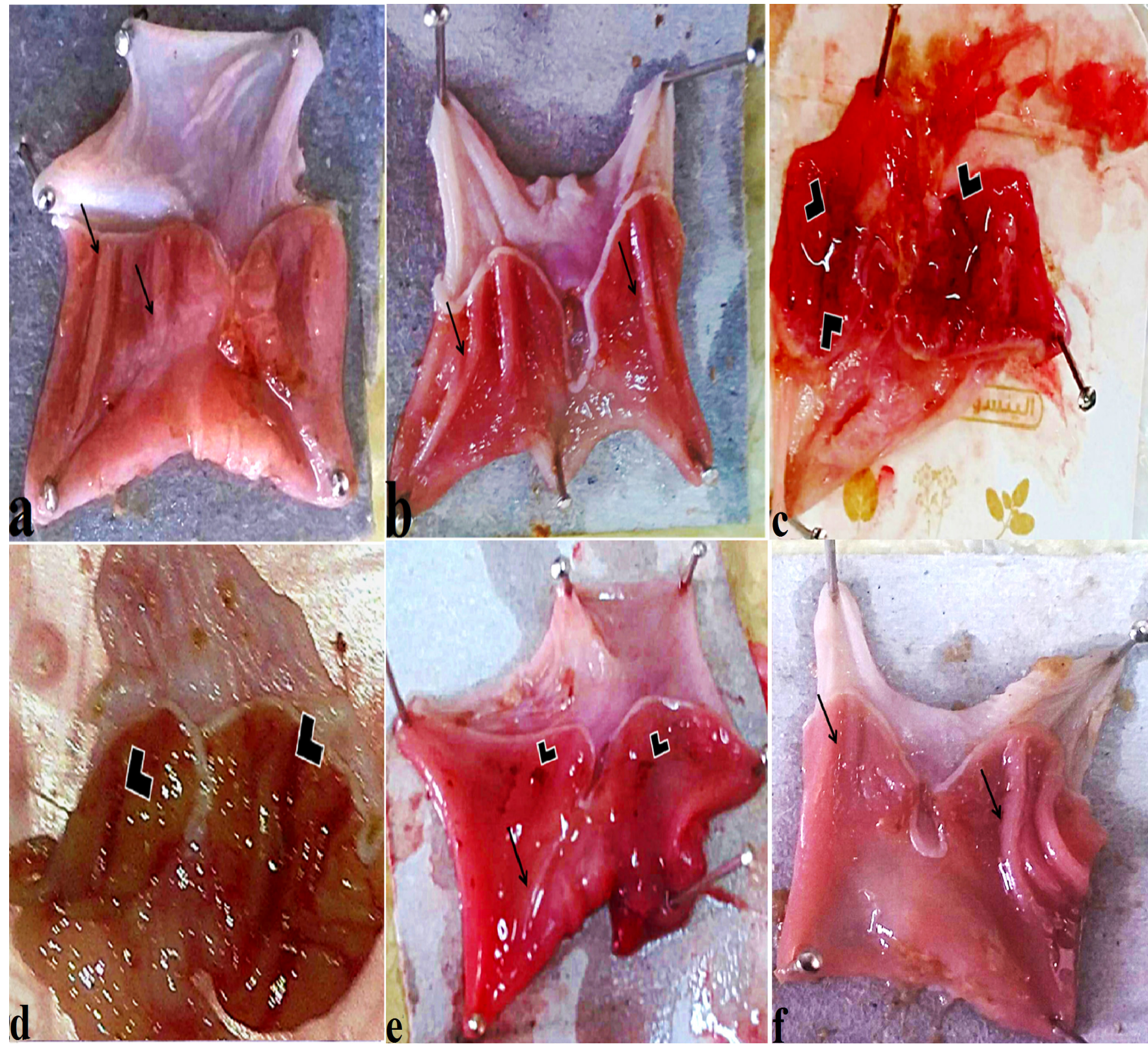

Fig. 1: Gross examination of the gastric mucosa of all experimental groups. (a, b): control (I) and caffeine groups (II) have normal gastric mucosa with prominent gastric rugae (arrows). (c): GIIIa shows dark red hyperemic patches and streaks within the gastric mucosa (arrowheads). (d): GIIIb, hyperemic streaks (arrowheads) scattered throughout the mucosa are noticed. (e): GIIIc shows dark red pinpoint spots (arrowhead) scattered within the gastric mucosa (arrows). (f): GIV reveals gastric mucosa more or less as the control (arrows). 

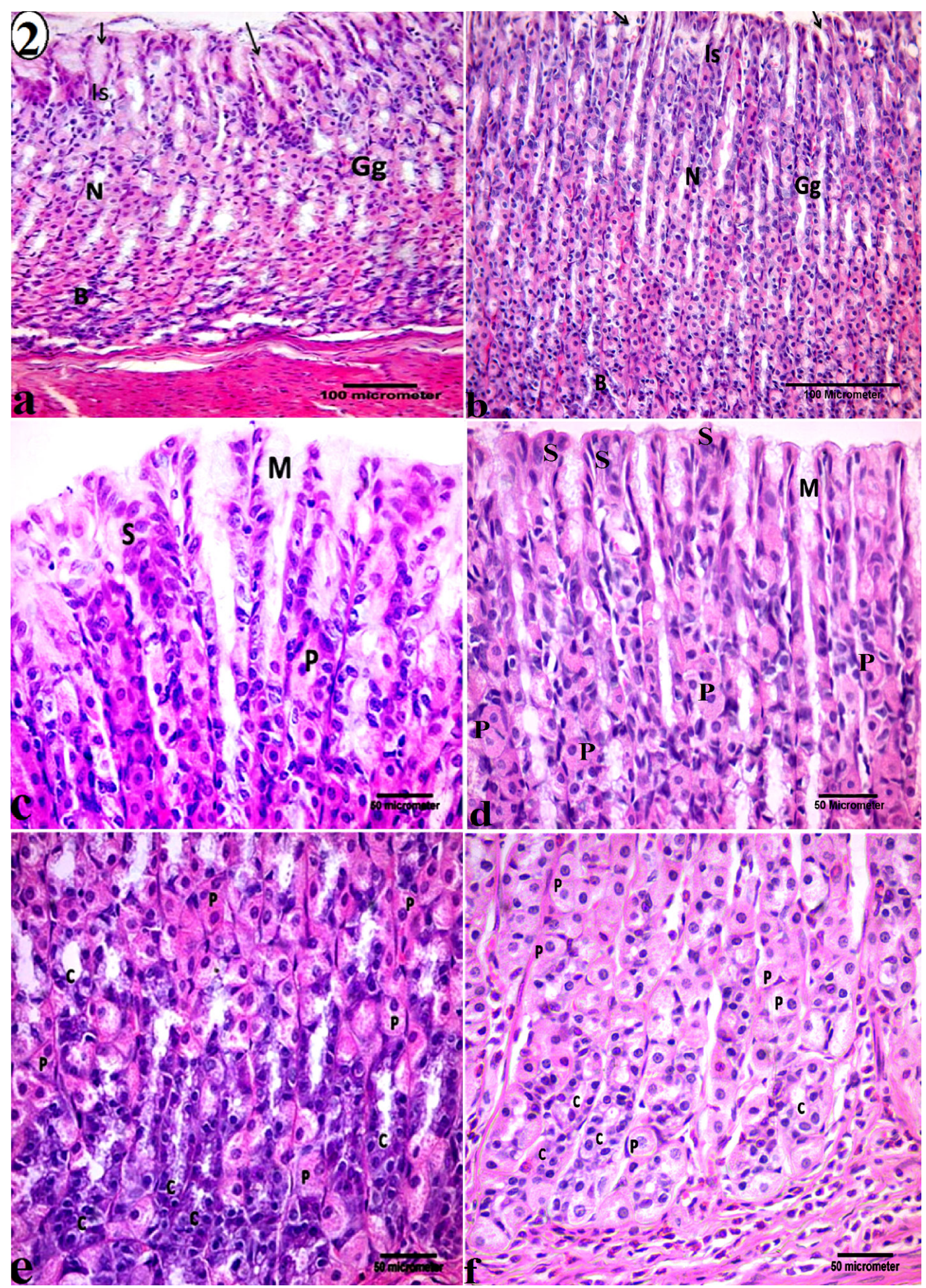

Fig. 2: Photomicrographs of the gastric mucosa from the control (GI) and caffeine groups (II), showing: (a, b) gastric pits (arrows), closely packed tubular gastric glands $(\mathrm{Gg})$ composed of the isthmus (Is), neck $(\mathrm{N})$ and base (B). (c,d) surface columnar epithelium (S), mucous neck cell (M) line the apical part of the gastric glands. Parietal cells (P) are also noticed. (e,f) Pyramidal parietal cells (P), as well as numerous low columnar chief cells (C), line the base region of glands. (H\&E; (a,b) x 200, scale bar $=100 \mu \mathrm{m} \&$ (c-f) x 400, scale bar $=50 \mu \mathrm{m}$ ) 


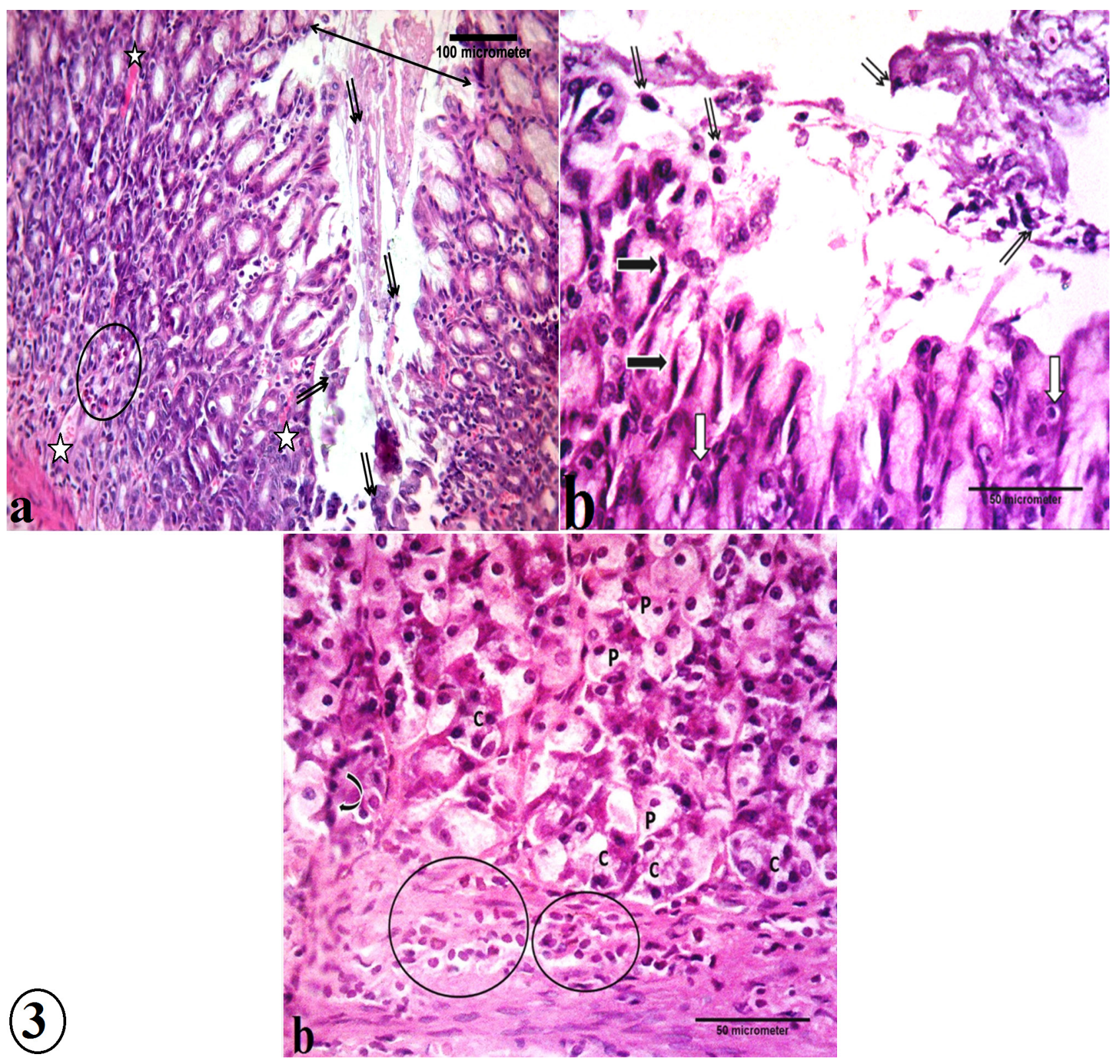

Fig. 3: Photomicrographs of the gastric mucosa from the gastric ulcer group (GIIIa), showing: (a) gastric ulcer (double-headed arrow) with desquamated cells and acidophilic tissue remnants (double arrows). Congestion of blood vessels (white stars) and inflammatory cell infiltrations (circle) in the lamina propria can be seen. (b) desquamated cells (double arrows), pyknotic surface epithelial cells (black arrows) and mucous neck cells (white arrows). (c) vacuolated parietal (P) and chief cells (C). Some deeply stained chief cells with dark pyknotic nuclei (curved arrows) are also observed. Notice, inflammatory cell infiltrations within the lamina propria (circle). (H\&E; (a) x 200, scale bar $=100 \mu \mathrm{m} \&$ (b,c) x 400, scale bar $=50 \mu \mathrm{m}$ ) 


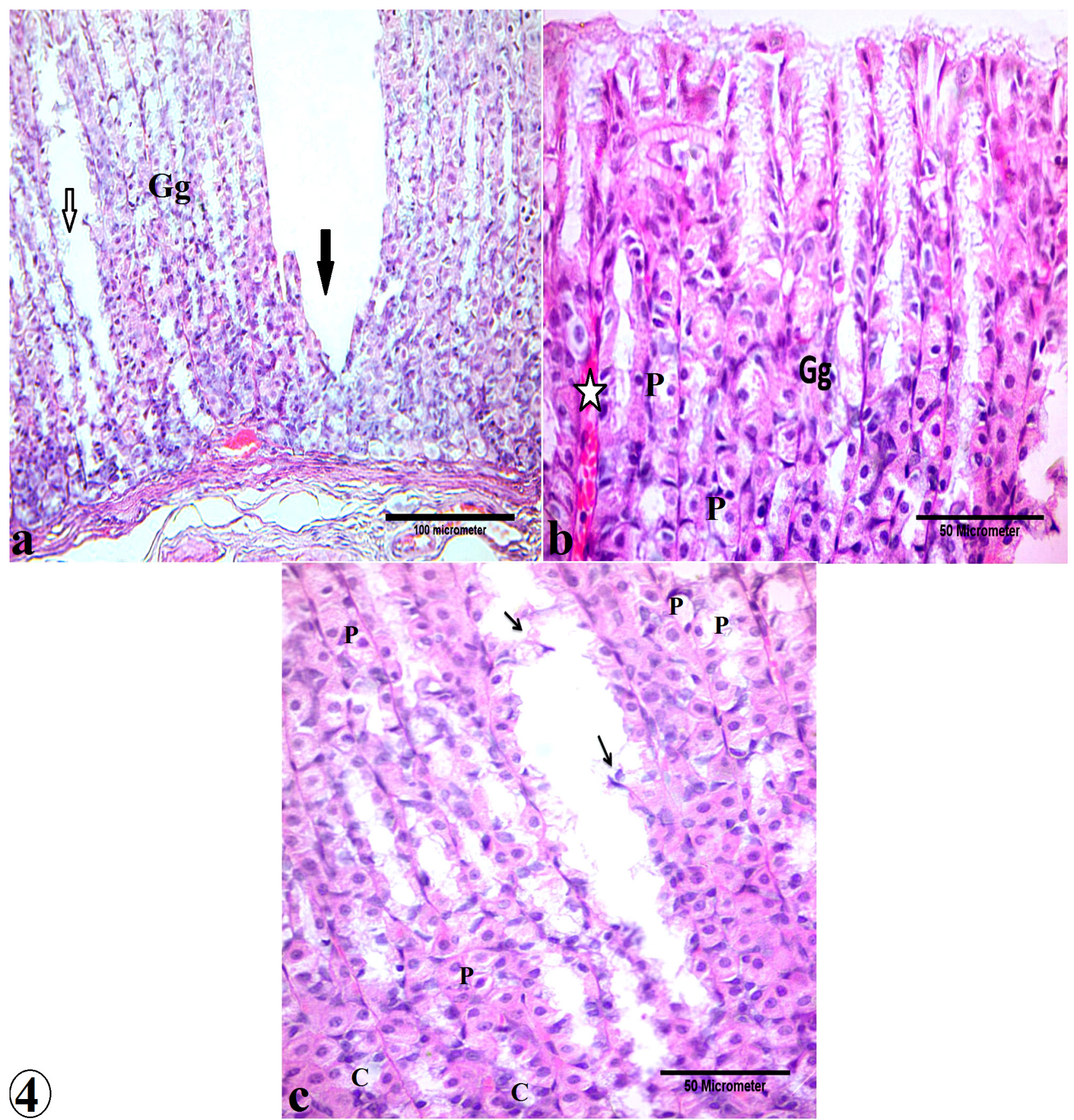

Fig. 4: Photomicrographs of the gastric mucosa from the untreated gastric ulcer group (GIIIb), showing: (a) gastric glands (Gg), unhealed gastric ulcer (black arrow) and unhealed deep part of gastric ulcer (white arrow) (b) healed superficial epithelium of the gastric glands (Gg), vacuolated parietal (P) cells and congested dilated blood vessels (white star). (c) detached cells (thin arrow) at the deep part of the unhealed ulcer. The parietal and chief cells (C) are more or less as in control group. Few vacuolated parietal cells (P) are also observed. (H\&E; (a) x 200, scale bar=100 $\mu \mathrm{m} \&$ (b,c) x 400, scale bar=50 $\mu \mathrm{m}$ ) 


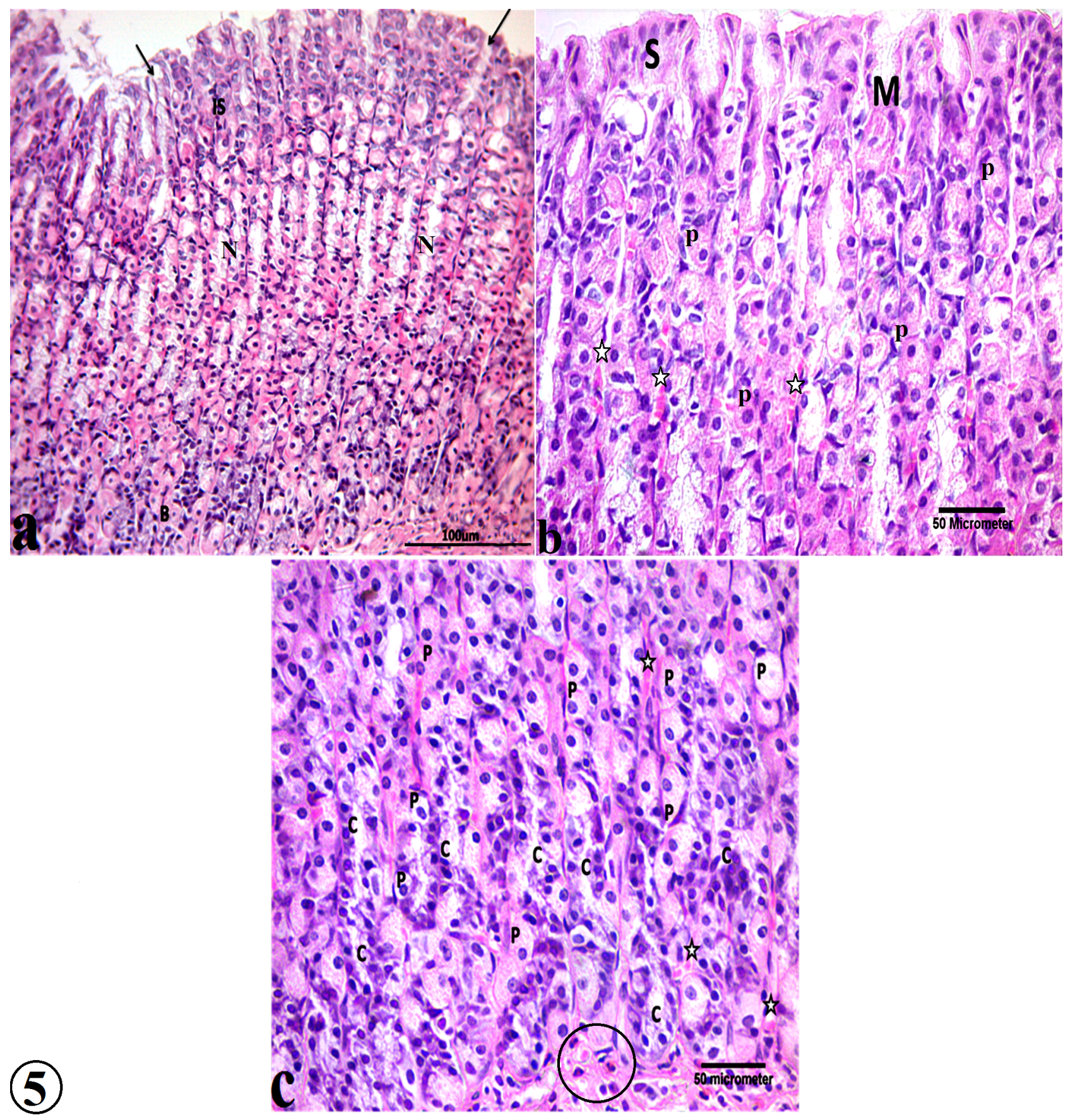

Fig. 5: Photomicrographs of the gastric mucosa from the treated group (GIIIc), showing: (a) a near-normal gastric mucosa, gastric pits (arrows), and closely packed gastric gland formed of the isthmus (Is), neck (N), and base (B). (b) surface columnar cells (S), mucous neck cell (M) and parietal cells (P) line the upper part of the gland nearly as the control group. Congestion of blood vessels (white stars) and few extravasation of RBCs between the gastric glands is also noticed. (c) Near-normal parietal (P) and chief cells (C) are at the basal part of the gland with extravasations of RBCs (white stars) and few inflammatory cells infiltration (circle) in the lamina propria between gastric glands. (H\&E; (a) x 200, scale bar=100 $\mu \mathrm{m} \&$ (b,c) $\mathrm{x} 400$, scale bar=50 $\mu \mathrm{m}$ ) 


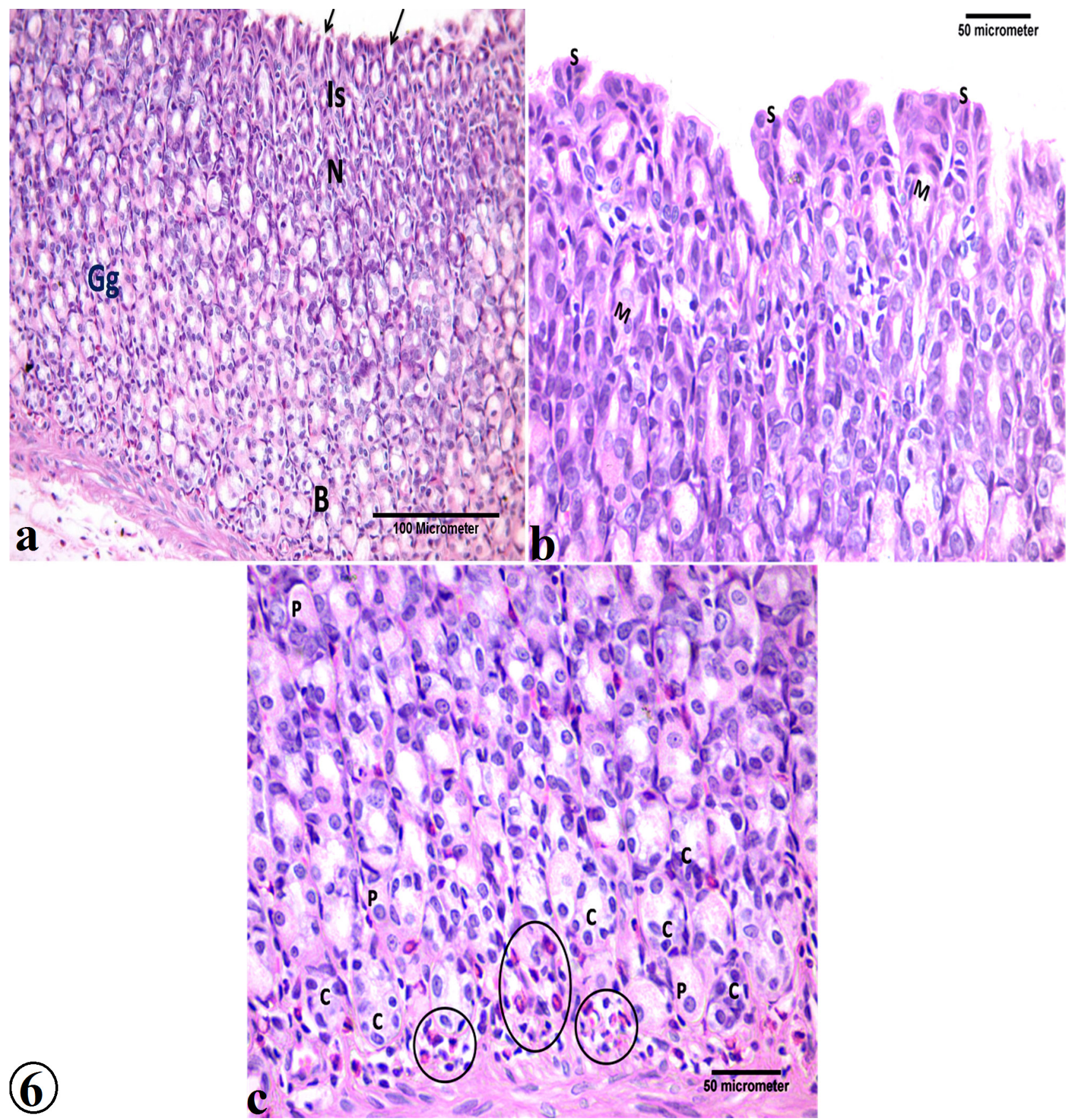

Fig. 6: Photomicrographs of the gastric mucosa from the prophylactic group (GIV), showing: (a) gastric pits (arrows), and closely packed gastric gland formed of the isthmus (Is), neck (N), and base (B). (b) surface columnar cells (S) and mucous neck cell (M) line the upper part of the gland is near as the control group. (c) normal parietal $(\mathrm{P})$ and chief cells $(\mathrm{C})$ line the basal part of the gland. Inflammatory cell infiltrations (circle) in the lamina propria are also observed. (H\&E; (a) x 200, scale bar $=100 \mu \mathrm{m} \&(\mathrm{~b}, \mathrm{c})$ x 400 , scale bar $=50 \mu \mathrm{m}$ ) 


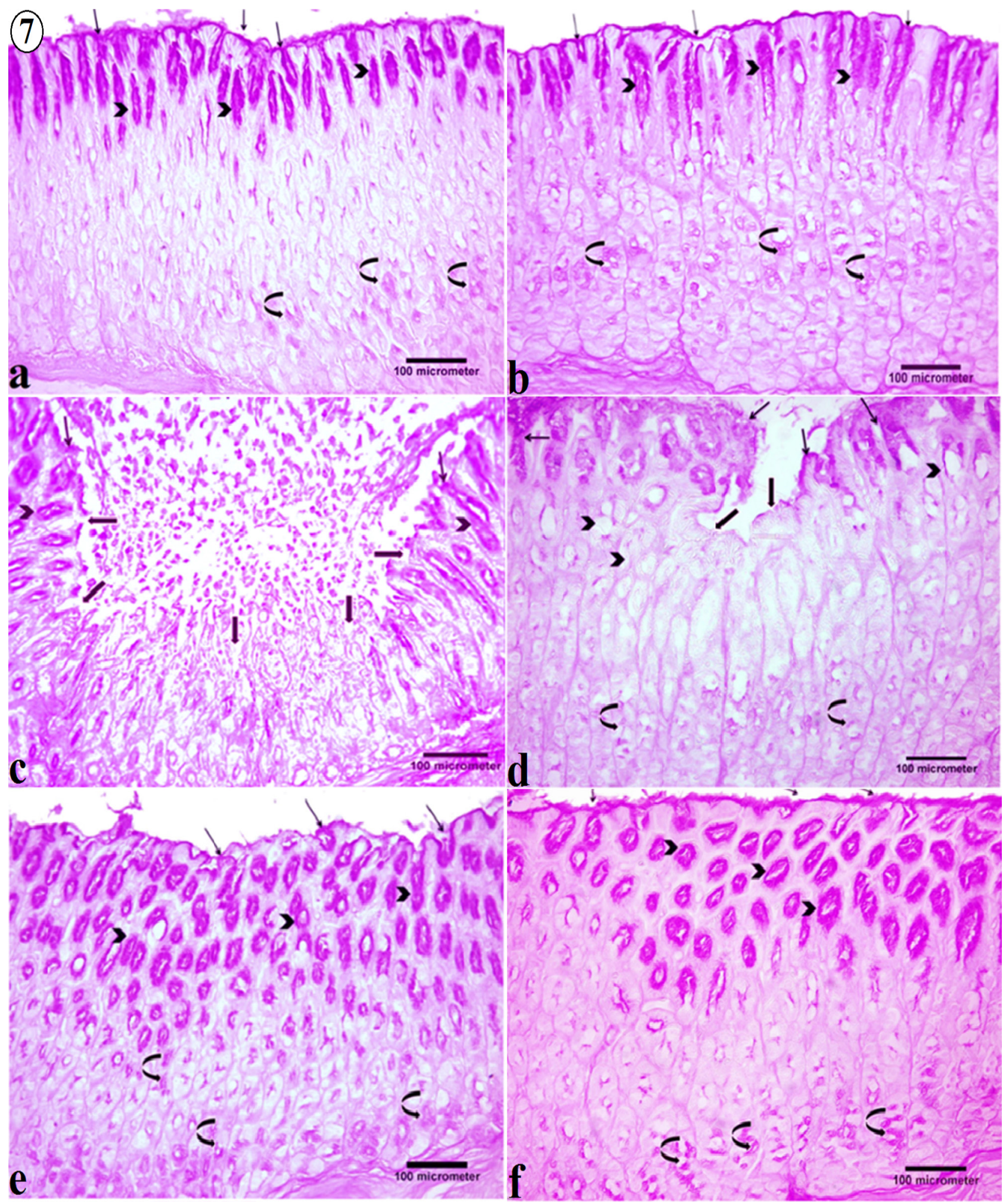

Fig. 7: Photomicrographs of the gastric mucosa from all experimental groups. (a, b): GI (control) and caffeine group (GII) reveal strong PAS-positive (+ve) reaction on the mucosal surface, down to pits (arrows), isthmus and neck regions (arrowheads) of the gastric glands. Weak PAS +ve reaction at the base regions (curved arrows) is noticed. (c,d) gastric ulcer groups (IIIa) and the untreated group (IIIb) reveal complete loss of PAS reaction at the ulcerated region (thick arrows), focal loss of the reaction over the eroded surface epithelium (thin arrows), , but strong PAS +ve reaction in the isthmus and weak reaction at the neck (arrowheads) and base regions (curved arrows) of the gastric glands. (e) treated group (IIIc) shows strong PAS +ve at the healed regions of the gastric glands over the surface epithelium, gastric pits (arrows), isthmus and neck regions (arrowheads). Notice, weak PAS reaction at the base region (curved arrows). (f) prophylactic group (IV) has a PAS reaction closely similar to the control. (Periodic acid Schiff reaction; x 200, scale bar=100 $\mu \mathrm{m}$ ) 


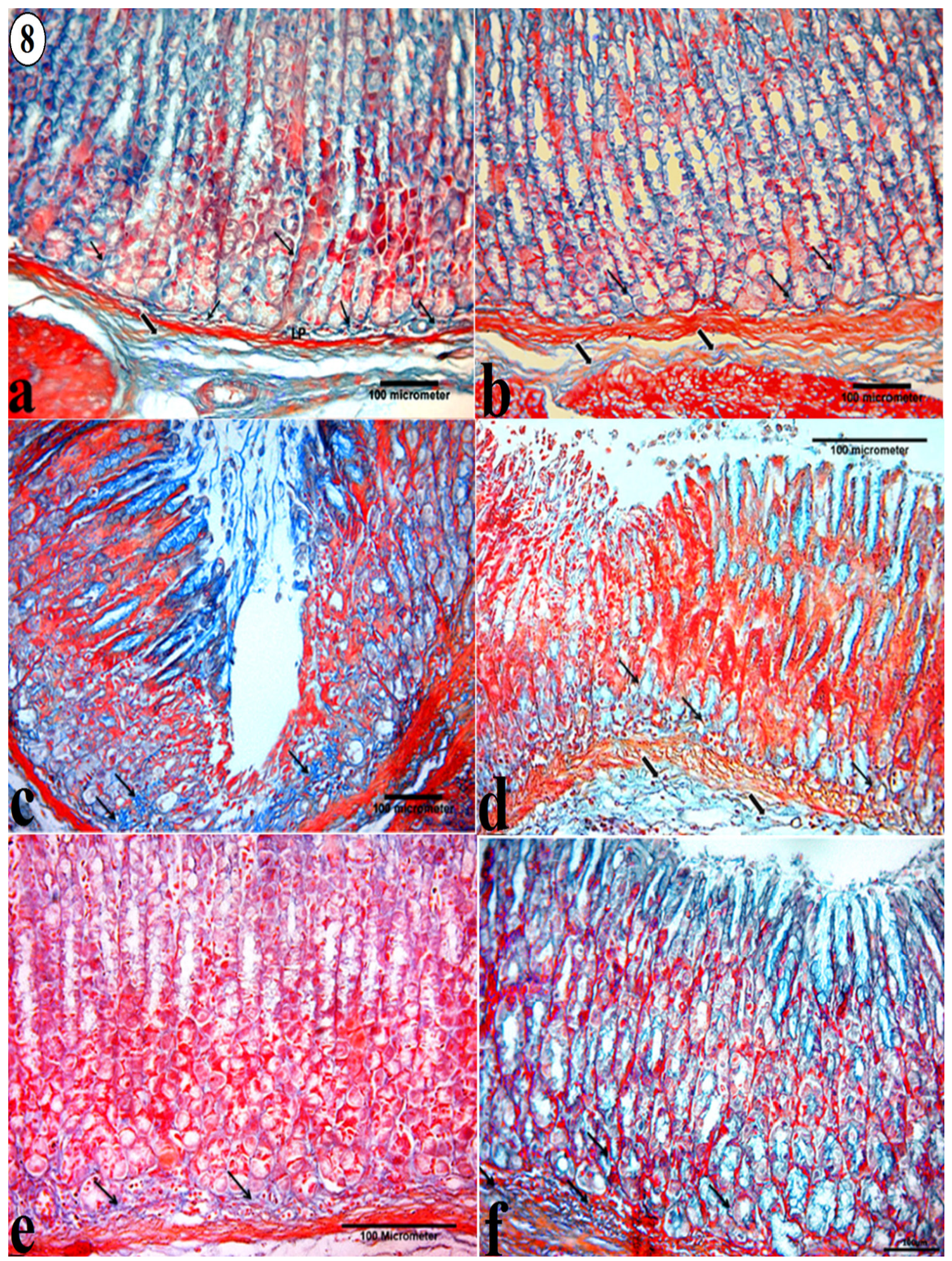

Fig. 8: Photomicrographs of the gastric mucosa from all experimental groups (a, b) control (GI) and caffeine group (GII) show fine and thin collagen fibers in the lamina propria (LP) between the gastric glands (thin arrows) and in the submucosa (thick arrows). (c,d) gastric ulcer group (GIIIa) and the untreated group (GIIIb) reveal increase in the distribution of the collagen fibers in the lamina propria between the gastric glands (thin arrows) and in the submucosa (thick arrows). (e) treated group (IIIc) shows fine collagen fibers in the lamina propria between gastric glands (arrows) comparable to the control group. (f) prophylactic group (GIV) reveals fine thin collagen fibers in the lamina propria between gastric glands (thin arrows). (Mallory's Trichrome; $\mathrm{x} 200$, scale bar $=100 \mu \mathrm{m})$ 


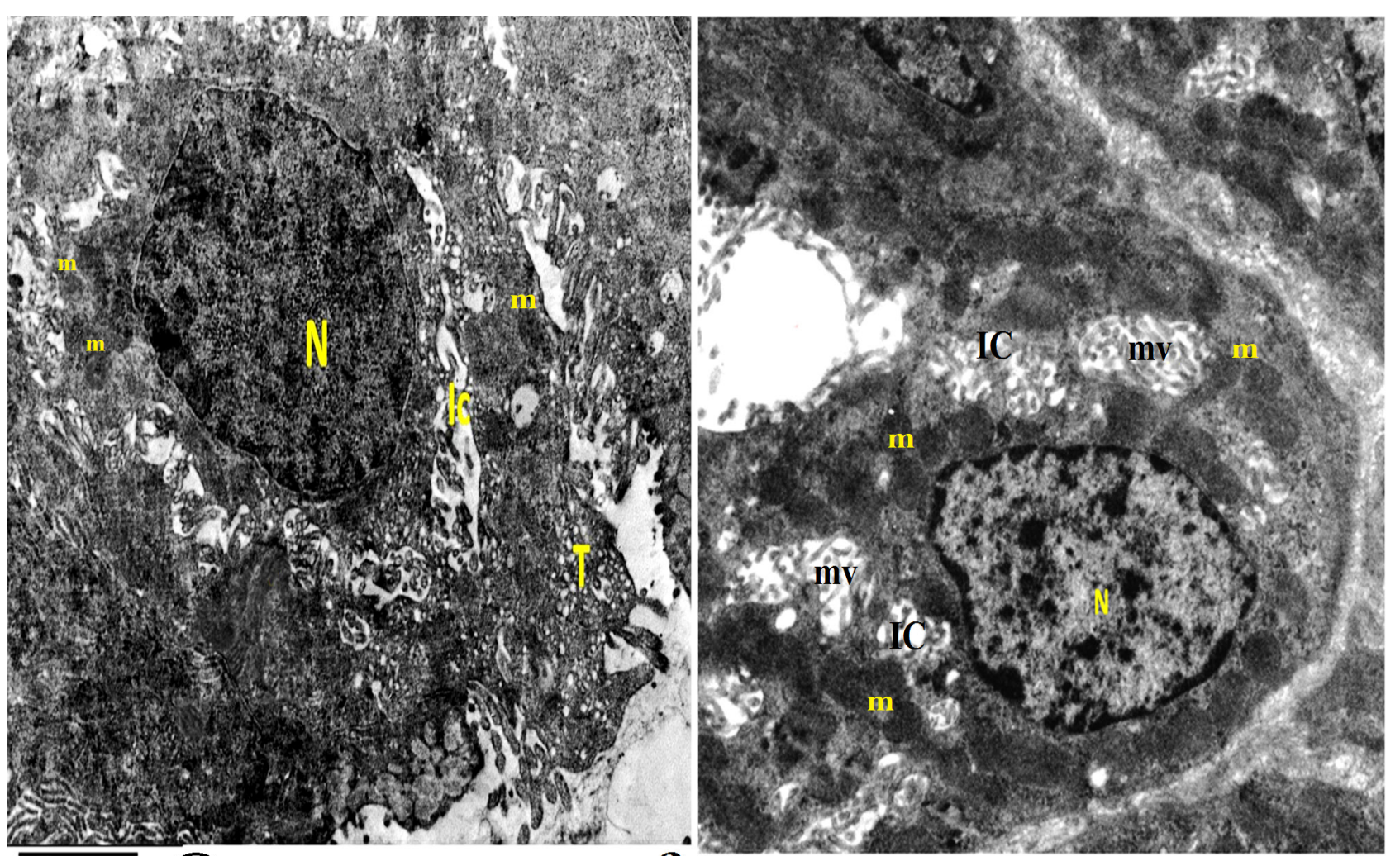

Fig. 9: Electron photomicrographs from the gastric gland of the control group (GI) and caffeine group (GII) showing: (a,b) parietal cells with rounded euchromatic nucleus $(\mathrm{N})$, intracellular canaliculi (IC) lined by microvilli $(\mathrm{mv})$ and the tubulovesicular structures $(\mathrm{T})$. Round to ovoid mitochondria (m) are noticed in the cytoplasm of the parietal cell. (Uranyl acetate \&Lead citrate; a,b x12000)
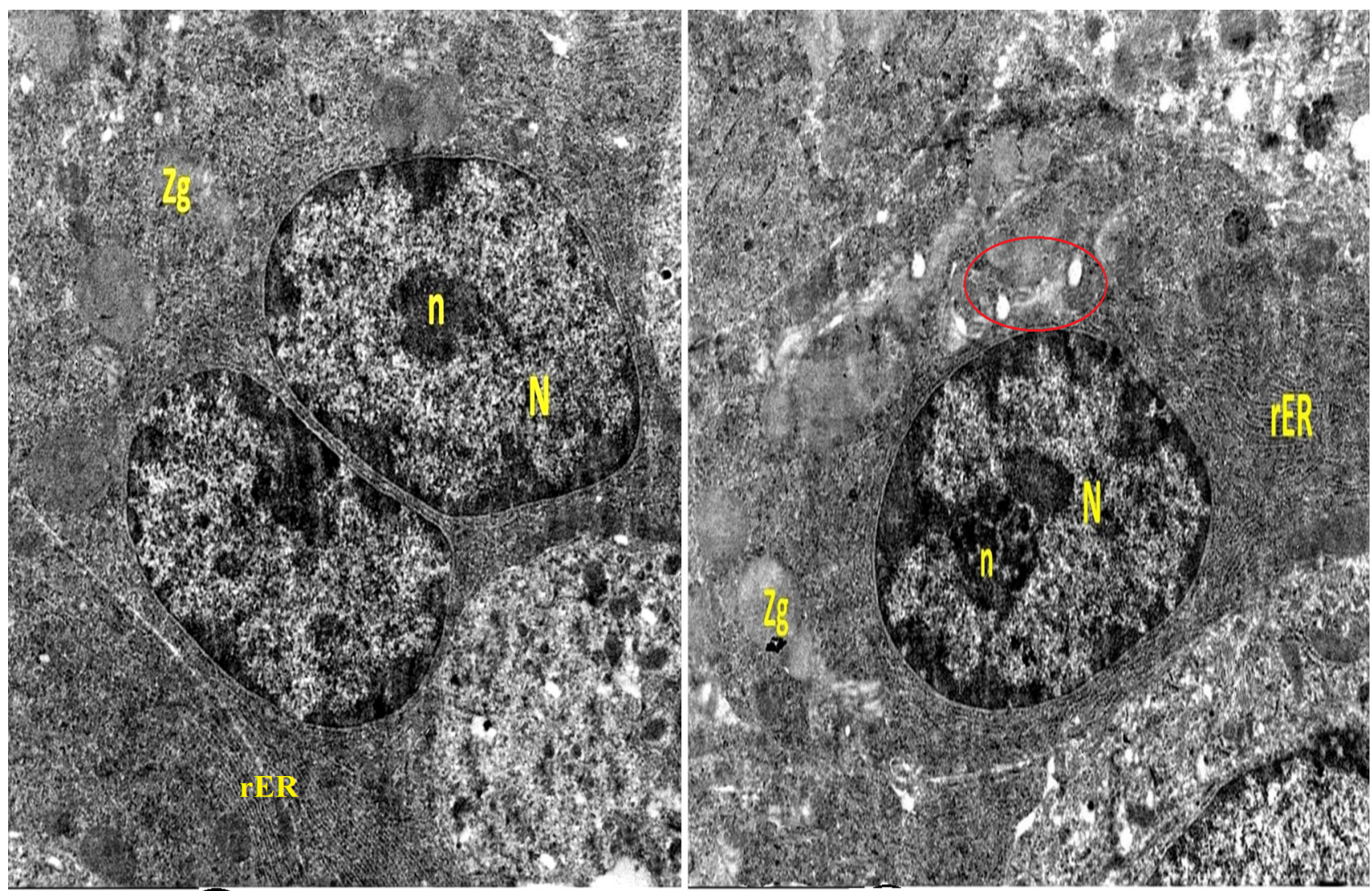

Fig. 10: Electron photomicrographs from the gastric gland of the control group (GI) and caffeine group (GII) showing: (a,b) chief cells have rounded euchromatic nuclei $(\mathrm{N})$ with prominent nucleoli $(\mathrm{n})$. The cytoplasm of chief cells depicts Golgi apparatus (circle), parallel stacks of the rough endoplasmic reticulum (rER) , mitochondria (m) and variable-sized electron-dense zymogen granules (Zg). (Uranyl acetate \&Lead citrate; a,b x12000) 

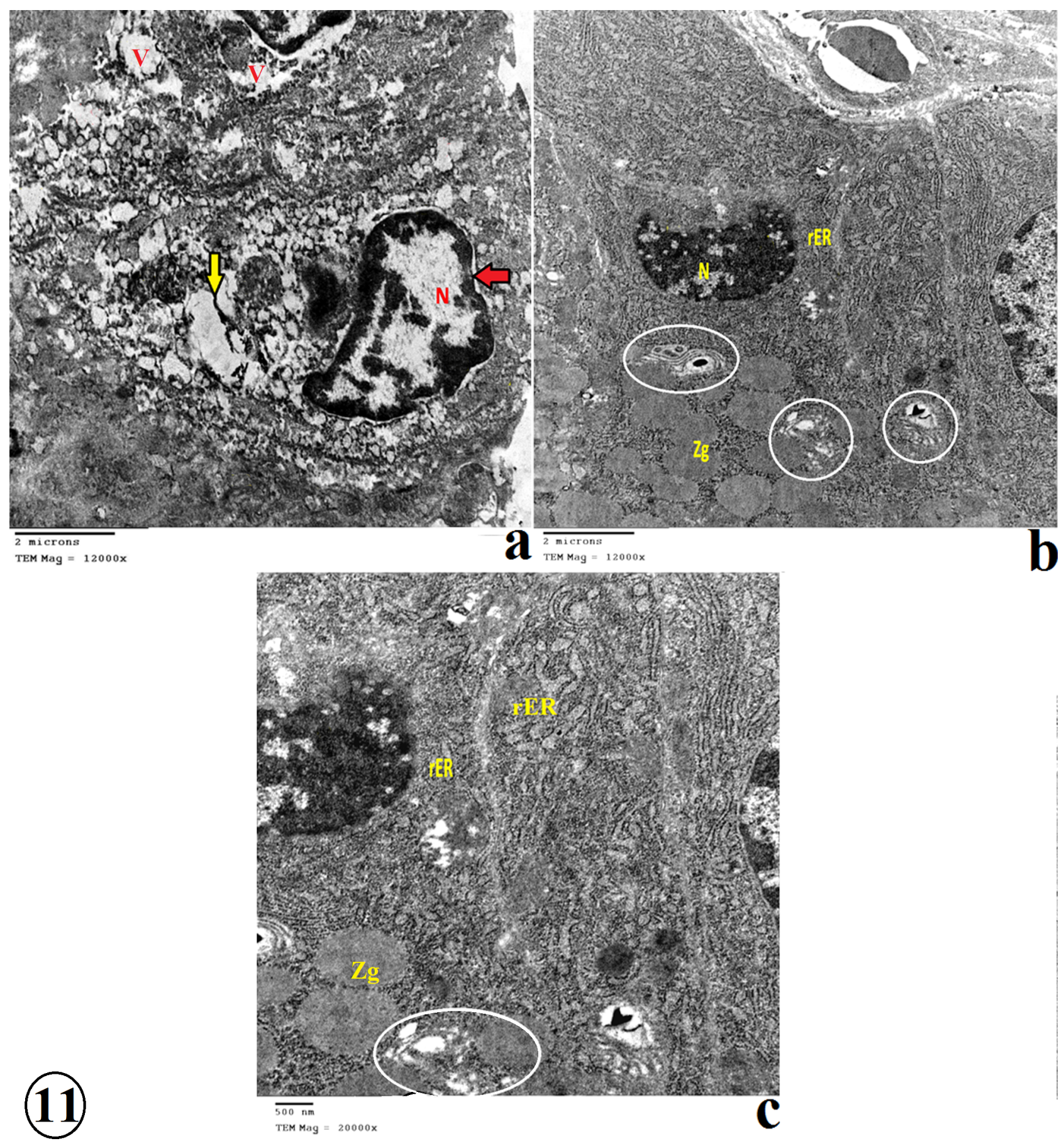

Fig. 11: Electron photomicrographs from the gastric gland of the gastric ulcer group (GIIIa) showing: (a) degenerated parietal cell has pyknotic nuclei (N) with dilated perinuclear cisternae (red arrow), distorted intracellular canaliculi (yellow arrow) and areas of cytoplasmic vacuolations (V). (b, c) chief cell shows shrunken pyknotic nucleus $(\mathrm{N})$ with condensed heterochromatin, dilated cisternae of the rough endoplasmic reticulum (rER), dilated Golgi apparatus (circles) and zymogen granules (Zg). (Uranyl acetate \&Lead citrate; a,b x12000 \& c x20000) 


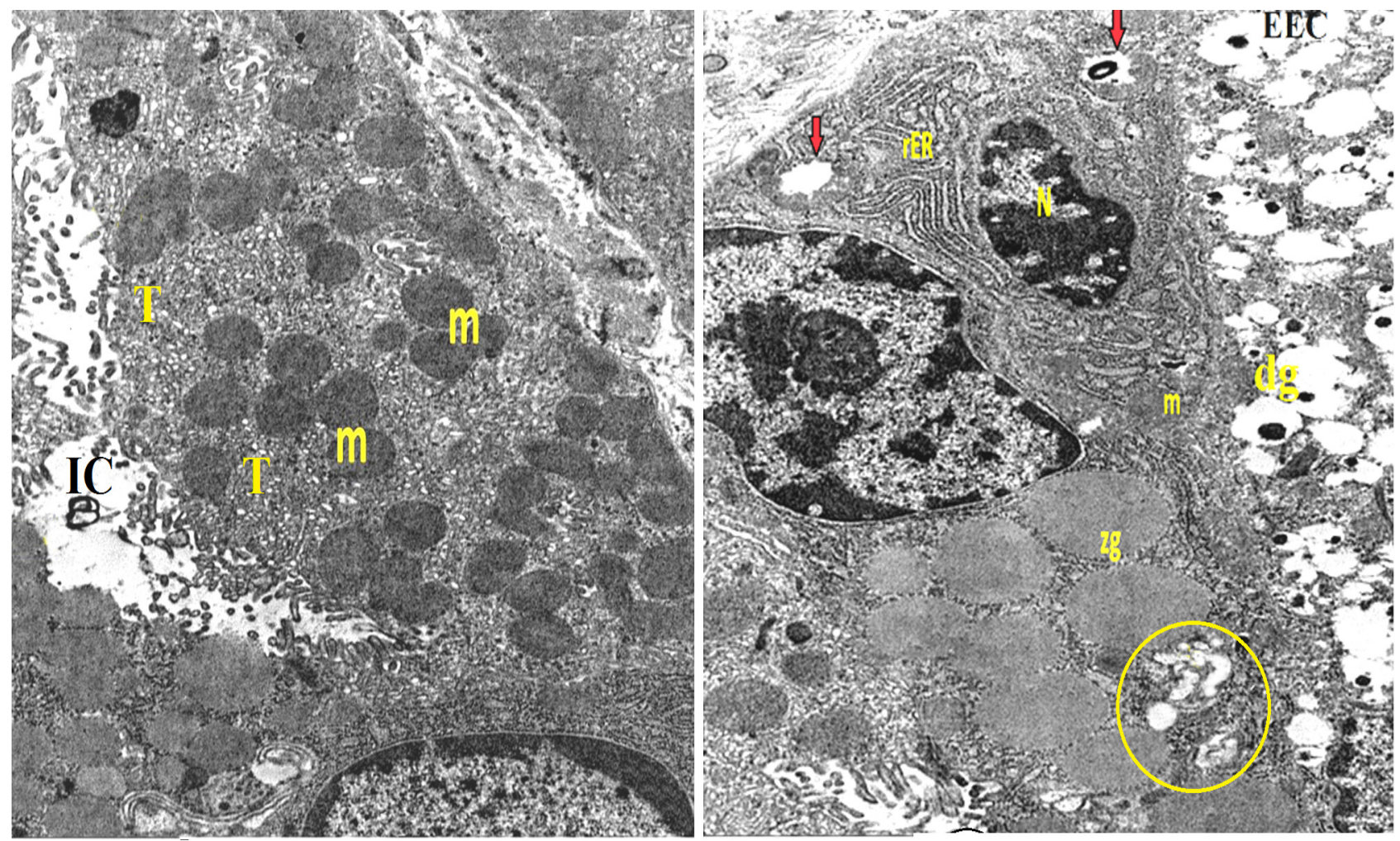

Fig. 12: Electron photomicrographs from the gastric gland from the untreated group (GIIIb), showing: (a) parietal cell with wide distorted intracellular canaliculi (IC) lined by damaged microvilli, tubulovesicular structures (T) and many swollen electron-dense mitochondria (m). (b) two adjacent chief cells, one has shrunken irregular nucleus $(\mathrm{N})$, dilated cisternae of the rough endoplasmic reticulum (rER), dilated Golgi saccules (circle), degenerated mitochondria with disrupted cristae (red arrows) and zymogen granules (Zg). Notice, part of the enteroendocrine cell (EEC) has degenerated granules (dg) in its cytoplasm. (Uranyl acetate \&Lead citrate; a,b x12000)

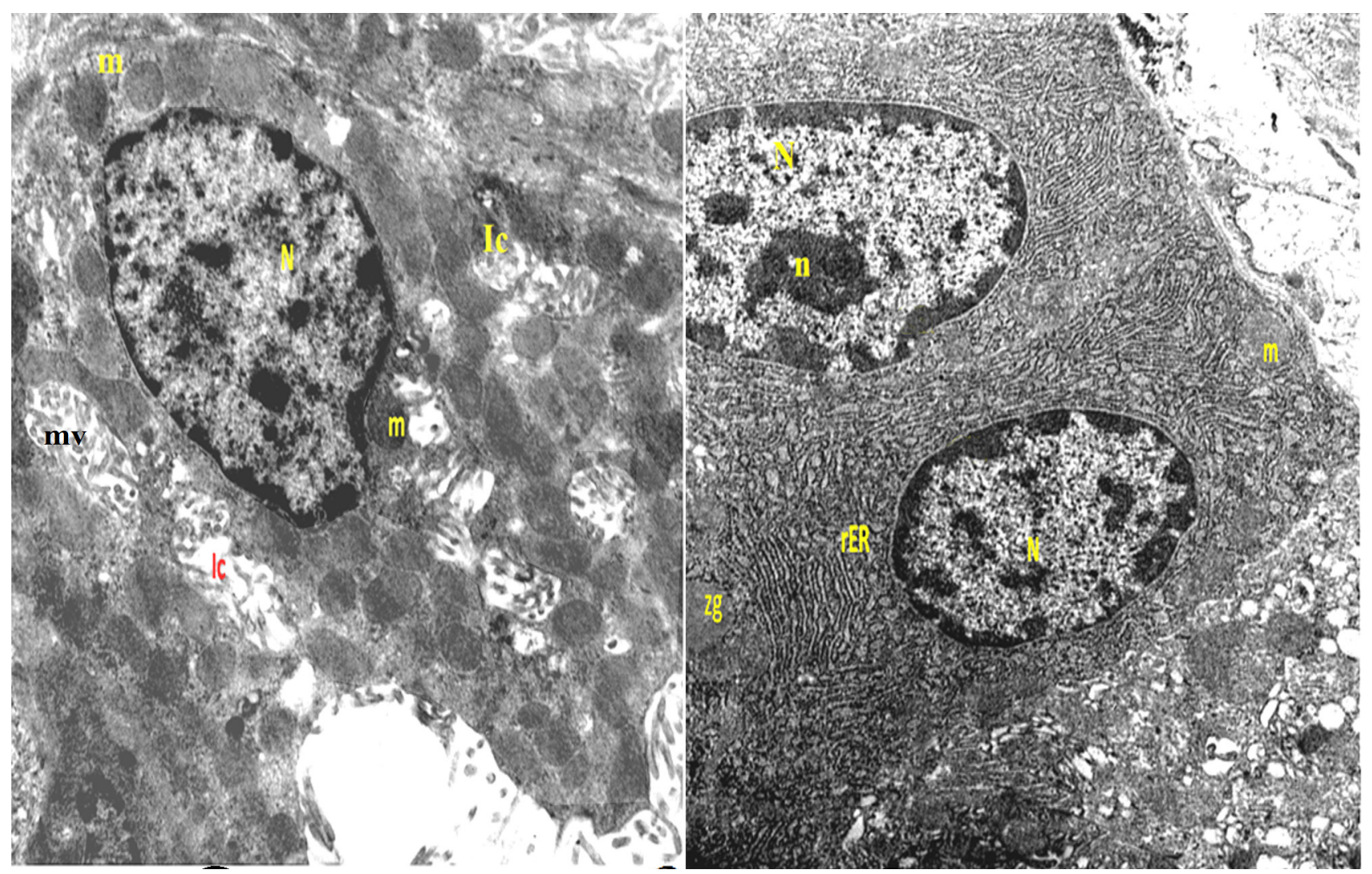

Fig. 13: Electron photomicrographs from the gastric gland of the treated group (GIIIc) showing: (a) normal parietal cells have euchromatic nucleus (N), intracellular canaliculi (IC) lined by microvilli (mv). Notice, round to ovoid electron-dense mitochondria (m). (b) chief cells have oval euchromatic nuclei (N) with prominent nucleoli (n), electron-dense zymogen granules $(\mathrm{Zg})$ and normal mitochondria. Dilated cisternae of the rough endoplasmic reticulum (rER) are also detected, (Uranyl acetate \&Lead citrate; a,b x12000) 

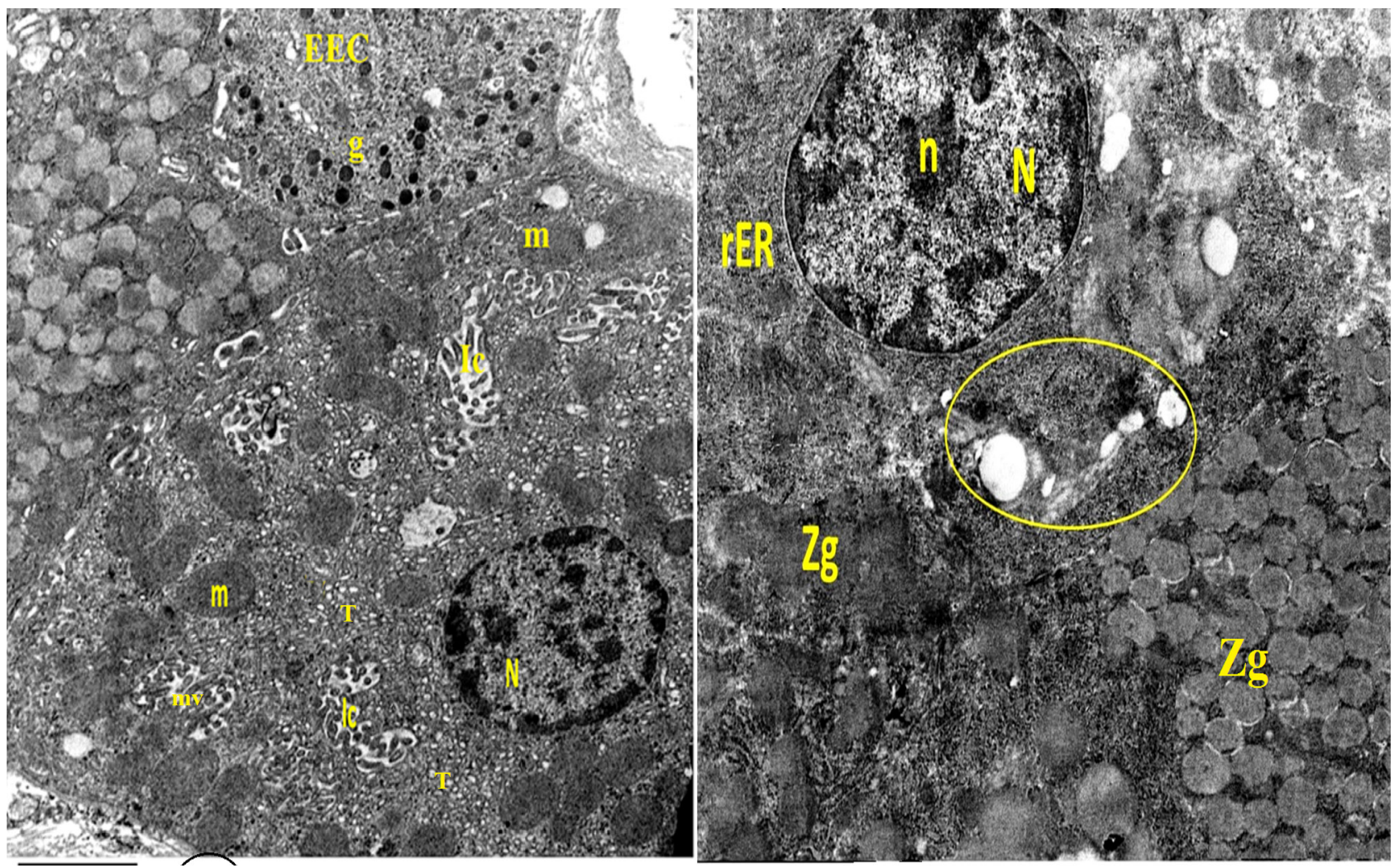

Fig. 14: Electron photomicrographs from the gastric gland of the prophylactic group (GIV), showing: (a) Normal parietal cell with rounded euchromatic nucleus $(\mathrm{N})$, intracellular canaliculi (IC) lined with microvilli (mv), prominent tubulovesicular system (T) and mitochondria (m) in cytoplasm. Part of an enteroendocrine cell (EEC) with many cytoplasmic electron-dense granules (g) is noticed. (b) the chief cell has euchromatic nuclei (N) with prominent nucleoli (n), regular cisternae of the rough endoplasmic reticulum (rER), Golgi apparatus (circle) and zymogen granules (Zg) more or less as the control group. (Uranyl acetate \&Lead citrate; a,b x12000)

Table 1: One-way ANOVA comparative statistical analysis of the mean initial and final body weight in rats of different groups

\begin{tabular}{lcccccccc}
\hline & Groups & GIA & GIB & GII & GIIIa & GIIIb & GIIIc \\
parameters & $\mathrm{N}=6$ & $\mathrm{~N}=6$ & $\mathrm{~N}=6$ & $\mathrm{~N}=6$ & $\begin{array}{c}\text { GIV } \\
\mathrm{N}=6\end{array}$ & $\begin{array}{c}p \text {-value } \\
\mathrm{N}=6\end{array}$ \\
\hline Initial body weight $(\mathrm{g} \pm \mathrm{SD})$ & $151.8 \pm 7.1$ & $149.8 \pm 4.1$ & $152.3 \pm 5.3$ & $149 \pm 8.5$ & $150.3 \pm 8.7$ & $152.3 \pm 5.9$ & $151.3 \pm 7.1$ & 0.98 \\
Final body weight $(\mathrm{g} \pm \mathrm{SD})$ & $185 \pm 5.8$ & $162.3 \pm 4.8$ & $181.7 \pm 7.5^{\square}$ & $133.8 \pm 8.6^{\star}$ & $126.7 \pm 6.1$ & $175.3 \pm 6.1^{\square}$ & $179.8 \pm 7.1^{\square}$ & 0.001 \\
\hline
\end{tabular}

SD: standard deviation; N: number of animals

A A significant decrease compared with all other groups.

$\square$ A significant increase compared with the gastric ulcer groups (GIIIa, GIIIb).

Table 2: One-way ANOVA comparative statistical analysis of the mean values of TAC (mM/L), PGE2 (pg/ml) and TNF- $\alpha(\mathrm{pg} / \mathrm{ml})$ in rats of different groups

\begin{tabular}{|c|c|c|c|c|c|c|c|c|}
\hline parameters & $\begin{array}{l}\text { GIA } \\
\mathrm{N}=6\end{array}$ & $\begin{array}{l}\mathrm{GIB} \\
\mathrm{N}=6\end{array}$ & $\begin{array}{c}\mathrm{GII} \\
\mathrm{N}=6\end{array}$ & $\begin{array}{c}\text { GIIIa } \\
\mathrm{N}=6\end{array}$ & $\begin{array}{c}\text { GIIIb } \\
\mathrm{N}=6\end{array}$ & $\begin{array}{l}\text { GIIIc } \\
\mathrm{N}=6\end{array}$ & $\begin{array}{l}\text { GIV } \\
\mathrm{N}=6\end{array}$ & $p$-value \\
\hline $\mathrm{TAC} \mathrm{mM} / \mathrm{L}$ & $1.12 \pm 0.4$ & $1.06 \pm 0.5$ & $0.97 \pm 0.1^{\square}$ & $0.52 \pm 0.1^{\wedge}$ & $0.52 \pm 0.1^{\wedge}$ & $0.84 \pm 0.1^{\text {Бо }}$ & $0.88 \pm 0.1^{\square 0}$ & 0.001 \\
\hline $\mathrm{PGE}_{2} \quad(\mathrm{pg} / \mathrm{ml})$ & $19994 \pm 1433$ & $20363 \pm 1603$ & $19861 \pm 982^{\square}$ & $2943 \pm 852 \boldsymbol{\Delta}$ & $5118 \pm 1141^{\wedge}$ & $15801 \pm 955^{\square o}$ & $17069 \pm 972^{\square о}$ & 0.001 \\
\hline TNF- $\alpha \quad(p g / m l)$ & $32.3 \pm 1.5$ & $33.3 \pm 1.9$ & $31.7 \pm 1.1$ & $65.2 \pm 2.6=$ & $58.1 \pm 3.0$ - & $27.7 \pm 2.0$ & $29.7 \pm 0.6^{\leftarrow 0}$ & 0.001 \\
\hline
\end{tabular}

SD: standard deviation; $\mathrm{N}$ : number of animals

A A significant decrease compared with all other groups.

- A significant increase compared with all other groups.

- A significant increase compared with the gastric ulcer groups (GIIIa, GIIIb).

$\therefore$ A significant decrease compared with the gastric ulcer groups (GIIIa, GIIIb).

o A significant decrease compared with the control (GIA, GIB ). 
Table 3: One-way ANOVA comparative statistical analysis of the mean number of parietal cells/HPF among rats of the experimental groups

\begin{tabular}{lcccccccc}
\hline & Groups & GIA & GIB & GII & GIIIa & GIIIb & GIIIc & GIV \\
parameters & $\mathrm{N}=6$ & $\mathrm{~N}=6$ & $\mathrm{~N}=6$ & $\mathrm{~N}=6$ & $\begin{array}{c}p \text {-value } \\
\mathrm{N}=6\end{array}$ & $\begin{array}{c}\mathrm{N}=6 \\
\text { No. of parietal cells/HPF }\end{array}$ \\
\hline
\end{tabular}

SD: standard deviation; $\mathrm{N}$ : number of animals

- A significant increase compared with all other groups.

$\because$ A significant decrease compared with the gastric ulcer groups (GIIIa, GIIIb).

- A significant increase compared with the control (GIA, GIB ) and caffeine groups (GII).

Table 4: One-way ANOVA comparative statistical analysis of the mean $\%$ PAS positive reaction among rats of the experimental groups

\begin{tabular}{|c|c|c|c|c|c|c|c|c|c|}
\hline parameters & Groups & $\begin{array}{l}\text { GIA } \\
\mathrm{N}=6\end{array}$ & $\begin{array}{l}\text { GIB } \\
N=6\end{array}$ & $\begin{array}{c}\text { GII } \\
N=6\end{array}$ & $\begin{array}{c}\text { GIIIa } \\
\mathrm{N}=6\end{array}$ & $\begin{array}{c}\text { GIIIb } \\
\mathrm{N}=6\end{array}$ & GIIIc & $\begin{array}{l}\text { GIV } \\
\mathrm{N}=6\end{array}$ & p-value \\
\hline Mean $\%$ PAS & & $7.4 \pm 1.1$ & $7.5 \pm 0.6$ & $7.7 \pm 1.0$ & $4.4 \pm 0.4^{\Lambda}$ & $5.1 \pm 0.2^{\Delta}$ & $5.6 \pm 0.7 \mathbf{\Delta}^{\circ}$ & $6.3 \pm 0.43^{\square}$ & 0.001 \\
\hline
\end{tabular}

SD: standard deviation; N: number of animals

A A significant decrease compared with all other groups.

$\square$ A significant decrease compared with the gastric ulcer groups (GIIIa, GIIIb).

o A significant decrease compared with the control (GIA, GIB ) and caffeine groups (GII).

Table 5: One-way ANOVA comparative statistical analysis of the mean area percentage of collagen fibers among rats of the experimental groups

\begin{tabular}{|c|c|c|c|c|c|c|c|c|c|}
\hline parameters & Groups & $\begin{array}{l}\text { GIA } \\
\mathrm{N}=6\end{array}$ & $\begin{array}{l}\text { GIB } \\
\mathrm{N}=6\end{array}$ & $\begin{array}{c}\text { GII } \\
\mathrm{N}=6\end{array}$ & $\begin{array}{c}\text { GIIIa } \\
\mathrm{N}=6\end{array}$ & $\begin{array}{c}\text { GIIIb } \\
\mathrm{N}=6\end{array}$ & $\begin{array}{c}\text { GIIIc } \\
\mathrm{N}=6\end{array}$ & $\begin{array}{l}\text { GIV } \\
\mathrm{N}=6\end{array}$ & p-value \\
\hline Mean area $\%$ of collagen & & $0.2 \pm 0.08$ & $0.16 \pm 0.04$ & $0.18 \pm 0.06$ & $4.1 \pm 0.53$ & $5.94 \pm 0.53 \amalg$ & $1.79 \pm 0.45^{\ddagger 0}$ & $0.31 \pm 0.14$ & 0.001 \\
\hline
\end{tabular}

SD: standard deviation; N: number of animals

Significant increase compared with all other groups.

$\because$ A significant decrease compared with the gastric ulcer groups (GIIIa, GIIIb).

- A Significant increase compared with the control (GIA, GIB ) and caffeine groups (GII).

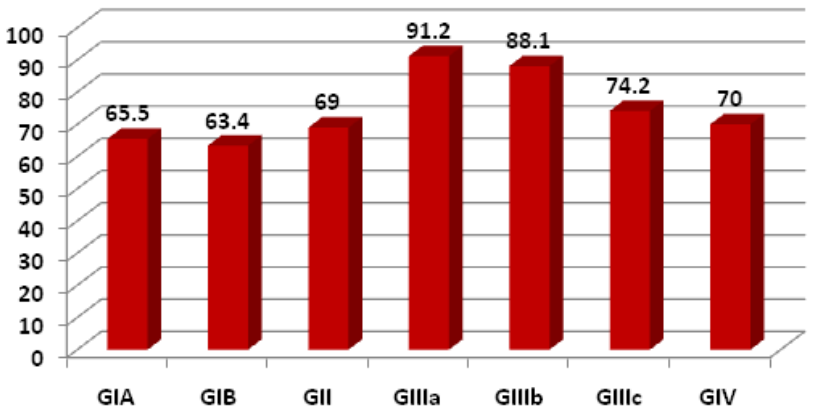

Histogram 1: No. of Parietal cells/HPF

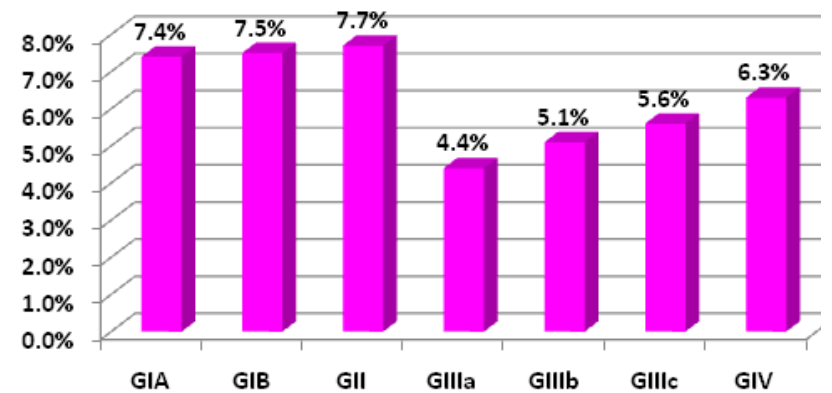

Histogram 2: the mean area percentage of PAS reaction among rats of all experimental groups

Histogram (3): the mean area \% of collagen

fibers among rats of all experimental groups

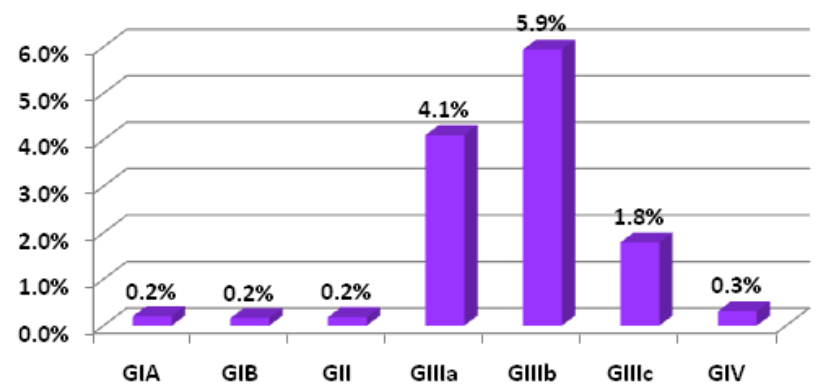

Histogram 3: the mean area $\%$ of collagen fibers among rats of all experimental groups 


\section{DISCUSSION}

Gastric ulcer (GU) is one of the most common and prevalent disorders of the gastrointestinal tract, reaching a considerable number of people around the world, and may become chronic and often recurring ${ }^{[19]}$.

Gastric ulcer is caused due to overproduction of injurious elements including gastric acid, pepsin, free radicals or decrease in protective factors including mucus, bicarbonates, and prostaglandins ${ }^{[20]}$.

Despite the advantages of non-steroidal antiinflammatory drugs (NSAIDs) but the unlimited usage of them should be restricted because of their multiple adverse effects including; gastrointestinal bleeding, cardiovascular side effects, and NSAID induced nephrotoxicity ${ }^{[5]}$.

Over 20 years ago, scientists put forward a significant association between coffee intake and gastroesophageal reflux syndrome that can ulcerate not only the gastroduodenal but also oesophagal mucosa in susceptible subjects $^{[21]}$. One of the most surprising recent studies stated that caffeine may decrease the extent of mucosal injury induced by oxidative stress because of its phenolic compounds. But its gastroprotective mechanisms are unclear $^{[22]}$

Since the data regarding the caffeine effects are contradictory, the present work was designed to investigate the effect of caffeine on the intact gastric mucosa and an aspirin-induced gastric ulcer in adult male albino rats using different biochemical and histological methods.

Rats were routinely used animal model for quick screening of different drugs as clinical studies are limited by ethical and logistic constraints ${ }^{[11]}$. The choice of adult male albino rat models was to avoid the effect of female sex hormone levels on the experimental study ${ }^{[23]}$

In the current study, the aspirin dose of $200 \mathrm{mg} / \mathrm{kg}$ once daily was recommended by Elgarawany et al. ${ }^{[4]}$ as the pathological characters of distorted gastric glands, a damaged mucosal epithelium and cell debris with ulcer formation were observed by using this dose.

Caffeine (1, 3, 7 trimethyl xanthine) administration was selected in an ideal daily dose of $300 \mathrm{mg} / \mathrm{kg}$ following the work of Pellizzon, et al. ${ }^{[11]}$. Interestingly Wilson, ${ }^{[24]}$ stated that caffeine is well known to have generally dose-dependent effects with positive or desirable effects at lower doses $(<400 \mathrm{mg})$ and undesirable effects generally above this level of intake.

The daily dose was given via an orogastric tube to ensure complete consumption of the established dose ${ }^{[11]}$.

The data from the present study on body weight showed that the least final body weight was significantly recorded among aspirin-induced gastric ulcer rats (GIIIa and GIIIb). On the contrary, final body weight was significantly increased among caffeine and treated rats (GIV and GIIIc), respectively.
The reduction in body weight in the ulcerated groups was in consistence with the work of Katherine et al ${ }^{[25]}$ who attributed that to the direct effect of NSAIDs on the gastric and intestinal mucosal cells concomitant with the inhibition of prostaglandins synthesis that ended with decreased nutrient digestion and absorption. Adefisayo et al. ${ }^{[26]}$ explained the reduction in the body weight to the anorexia that occurred to avoid the creep friction pain during gastric peristalsis after meals with increasing the area of the ulcer and the amount of gastric acid secretion which collectively stimulates the ulcer and aggravates the pain.

The increase in food consumption and body weight among caffeine groups was in consistence with Pellizzon, et $a l . .^{[11]}$ and Mazzafera \& Silvarolla ${ }^{[27]}$ who explained that by the effect of caffeine in the normalization of the prostaglandins and regaining the mucous gel layer which consequently relieves painful friction during peristalsis. Hence, caffeine is considered as one of the best therapeutic resources in gastroprotection in a rat gastroprotective model.

The data from the present study on measuring serum levels of tumour necrotic factor-alpha (TNF- $\alpha)$, total antioxidant capacity (TAC) and prostaglandin E2 (PGE2), showed a statistically significant increase of (TNF- $\alpha)$ expression coupling to a significant decrease in both serum PGE2 and TAC levels among gastric ulcer (GIIIa and GIIIb). On the contrary, there was a marked improvement in these parameters among caffeine prophylactic and caffeine treated rats (GIV and GIIIc), when compared to rats of the ulcer groups.

The disturbance in serum antioxidant enzymes expression in aspirin administrated groups were explained by Wongrakpanich, et al. ${ }^{[5]}$ who stated that NSAIDs are primarily enacted by their ability to block certain prostaglandins production through the inhibition of cyclooxygenase (COX-1 and COX-2) pathways. Suheryani et al..$^{[28]}$ and El-Azab et al. ${ }^{[29]}$ added that the noxious stimuli of high aspirin dose increase different cytokines expressions such as interleukins (IL-6, IL-8) and TNF- $\alpha$ which are directly chemotactic to leukocytes concomitant with a massive release of reactive oxygen species (ROS) that are key regulators of inflammatory processes with adenosine accumulation in the extracellular space as a consequence of oxidative stress which in turn may induce lipid peroxidation, inhibit antioxidant enzymes and become a harmful indicator in the pathological process of aspirin-induced gastric injury.

This was antagonised by a study of Elgarawany et al. ${ }^{[4]}$ who reported a specific compensatory overexpression of the antioxidant complex enzymes following aspirin administration to counteract the deleterious effects of reactive oxygen species (ROS) on the stomach, maintain gastric mucosal integrity and accelerate gastric mucosal healing.

The marked improvement in serum levels of (TAC) and (PGE2) coincide with a significant decrease in 
(TNF- $\alpha$ ) that was encountered with co-administration of caffeine (GIV, GIIIc) was following Pellizzon, et al. ${ }^{[11]}$ who attributed the antioxidant effect of caffeine and caffeic acid to the scavenging superoxide radicals and other reactive oxygen species (ROS) which could prevent subsequent neutrophils infiltration that are responsible for the damage of gastric mucosa generated by oxidative stress and lipid peroxidation.

Moreover, Köroğlu et al. ${ }^{[30]}$ in their study of the caffeine effects on newborns stated that blockade of adenosine A1 receptor by caffeine consumption inhibits the production of pre-transcriptional TNF- $\alpha$ by cord blood monocytes, hence exerting powerful anti-inflammatory effects.

Choosing the body of the stomach was following Siddiqui et al..$^{[31]}$ who reported that the predominance of parietal cells in the fundus and body regions of the stomach makes them the most common locations for gastric ulcerations.

The macroscopic dark red hyperemic lesions in the gastric mucosa that were observed in gastric ulcer groups (GIIIa, GIIIb) was attributed to stasis in gastric blood flow, congestion of submucosal blood vessels and submucosal oedema which contribute to the development of the haemorrhages and necrotic aspects of tissue injury ${ }^{[32]}$.

The current light microscopic results of gastric ulcer groups revealed focal discontinuity and distortion of gastric glands in the form of gastric ulcers, gastric erosions, sloughing of the superficial epithelium of the gastric glands along with inflammatory cell infiltrations, congested blood vessels with extravasated red blood corpuscles in the lamina propria between the glands.

These degenerative changes were going hand to hand with the data reported by Wongrakpanich et al ${ }^{[5]}$ and Mahmoud \& Abd El-Ghaffar ${ }^{[33]}$. These authors stated that NSAIDs-induced gastric ulceration is a neutrophil-dependent process and referred these changes to two mechanisms. First: ischaemia and reduced angiogenesis as a result of suppressing certain prostaglandins (PGs) synthesis through the inhibition of cyclooxygenase (COX-1\& COX-2) generation, impairing platelet aggregation, altering the microvascular structures and subsequent microvascular occlusion with activated and aggregated neutrophils which reduces the oxygen and nutrients supply that results in debilitating the defensive gastric mucosal barrier, diminishing mucus and bicarbonate secretion, oxidative stress induction which leads to epithelial damage, release pro-inflammatory mediators and increase leukocyte infiltration as well as decrease antioxidant enzymes predisposing to the ulcer with necrosis of the gastric mucosal cells and bleeding complications. Second: prostaglandin independent mechanisms, such as disruption of cell proliferation resulting in alterations of mucosal cell turnover and impaired epithelial regeneration. Moreover, disturbance of cell to cell interaction and decrease of epithelial integrity give rise to sloughing and desquamation.
Cryer and Mahaffey ${ }^{[34]}$ referred these changes to the direct mucosal irritation by aspirin, where the acidic media of the stomach directly converts aspirin and most NSAIDs into more lipid-soluble unionized acids and forces their accumulation in the gastric mucosal cells, which in turn alters the permeability of the cell, allows back-diffusion of acid and pepsin from the lumen into the mucosa and causes ulceration.

Rubin \& Strayer ${ }^{[35]}$; Bjarnason et al. ${ }^{[36]}$ \& Radwan et $a{ }^{\left[{ }^{[37]}\right.}$ have pinpointed low oxygen tension and depletion of adenosine triphosphate (ATP) generation inside the cells as the fundamental link associating the damaging effect of NSAIDs, consequently interfere with ATP-dependent $\mathrm{Na}+/$ $\mathrm{K}+$ pump by increasing the permeability of cell membrane to sodium leading to accumulation of sodium in the cell and an osmotic gain of water along with intracellular calcium influx from the extracellular fluid and its release from intracellular stores that would activate proteases, phospholipases and endonucleases leading to surface epithelium exfoliation.

Bjarnason et al.$^{[36]}$ attributed changes in chief cells to the aggressive effect of pepsin and lipase on the mucosal lining, especially if associated with decreased mucus secretion and therefore induce direct damage and finally cause cell necrosis as confirmed by electron microscopic findings.

Distortion of gastric glands that were detected in the current study could be justified by the work of Radwan et $a{ }^{\left[{ }^{[37]}\right.}$ who attributed that to the proliferation of parietal cells as well as the glandular hypersecretion, which might be related to inhibition of prostaglandin I2 (PGI2), a potent anti-secretory agent. This was confirmed by a significant increase in the parietal cells count in the ulcer groups. Ezemagu et al. ${ }^{[38]}$ added that the new parietal cells are probably recruited from existing precursor cells and are not formed directly from dividing cells.

On the contrary Abd El-Salam et al. ${ }^{[39]}$ found in their study on the ulcerated groups a significant decrease in most cells lining the fundic glands. They attributed this to the sloughing and destruction of the mucosal epithelial cells that extended along the length of the fundic glands from the neck to the base.

The inflammatory cellular infiltration observed in the ulcerated group might be due to the neutrophil-endothelial cell interactions with increased adhesion between neutrophils and vascular endothelial cells in both the gastric and mesenteric venules ending with the release of a variety of inflammatory mediators from the activated neutrophils which might be involved in the pathogenesis of gastric mucosal injury ${ }^{[40]}$.

Mahmoud \& Abd El-Ghaffar ${ }^{[33]}$ added that the inflammatory infiltration might occur from the imbalance between the noxious agents and the gastroprotective mechanisms stimulating the release of IL- 1 and TNF- $\alpha$ leading to the infiltration of gastric mucosa with 
inflammatory cells. Also, Elwan \& Ibrahim ${ }^{[40]}$ attributed this to the junctional complexes disturbance between the surface epithelial linings by NSAIDs with subsequent bacterial invasion which might be chemotactic for neutrophils, lymphocytes and macrophages.

Arisha $^{[41]}$ attributed congested blood vessels to the destructive action of aspirin on the mucosal barrier ending with exposure of capillaries and venules to the harmful effect of hydrochloric acid in the gastric secretion. He also stated that inflammatory cellular infiltration of different kinds of cells mainly mast cells with histamine and leukotrienes release as a consequence of neutrophil activation caused vasodilatation and increase vascular permeability and migration of inflammatory cells.

In the present study, caffeine exerts no harmful effect on the histological structure of the normal gastric mucosa in the group (II) which appeared more or less as the control group. Caffeine prophylactic group (GIV) appeared to be more resistant to the destructive effect of aspirin. Moreover, marked improvement in the histological structure of the gastric mucosa was detected in the treated group (GIIIc) that was almost recovered despite slight inflammatory cell infiltration in-between the base of the glands.

To our knowledge, there is no scientific report on the histological effect of caffeine on the gastric mucosa. However, many experimental studies referred the gastroprotective potential of caffeine to the high natural antioxidant compounds in coffee seeds residue that can reduce free radicals, pro-inflammatory mediators and protect biological molecules from oxidative injury thus avoid the occurrence of the gastric ulcer ${ }^{[1,11,42]}$. Ezemagu et $a l \cdot{ }^{[43]}$ added that the potent natural antioxidant effect of caffeine might have protected the gastric mucosa through destruction of the proliferated parietal and chief cells associated with aspirin administration, with a consequent reduction in acid secretion and pepsinogen. This was confirmed in the present study by a significant reduction in the number of parietal cells in the caffeine groups (GIIIc, GIV).

A significant reduction in the area percentage of PAS-positive histochemical reaction with depletion of mucus on the surface of the distorted gastric glands in the ulcerated groups was attributed to the direct cytotoxic effect of aspirin on gastric mucous secreting cells with decreasing in their numbers, diminishing mucus production and mucus barrier dysfunction which is linked to the oxidative stress and the inflammatory infiltration ${ }^{[40]}$. Radwan et al. ${ }^{[37]}$ also reported that NSAIDs can decrease the hydrophobicity of the mucus gel layer in the stomach via association with the surface active-phospholipids and decreases the accumulation of prostaglandins through inhibiting the cyclooxygenase (COX-1) enzymes with decreased mucus production.

A significant increase in the area percentage of PASpositive reaction that was observed in caffeine groups (GIIIc and GIV) was in parallel with Abrahão et al. ${ }^{[6]}$ and Pellizzon, et al. ${ }^{[11]}$ who attributed that to the potent antioxidant effect of caffeine as there was a link between the mucus barrier dysfunction and the oxidative stress. This was confirmed by the study of Castro et al ${ }^{[42]}$ and De Mejia $\&$ Ramirez-Mares ${ }^{[44]}$ who reported a statistically significant increase in serum and tissue antioxidant agents (Reduced glutathione (GSH), Glutathione peroxidase (GPx) and Glutathione Reductase (GR) with caffeine consumption.

A significant increase the density and distribution of the collagen fibers in the lamina propria and in the submucosa that was detected in Mallory's trichrome stained sections after aspirin administration in GIIIa, GIIIb could be explained by Mahmoud \& Abd El-Ghaffar ${ }^{[33]}$ who stated that fibrosis is simply the consequences of reactive oxygen species overproduction, apoptosis dysregulation and increase proinflammatory cytokines expressions such as TNF- $\alpha, \mathrm{C}$-reactive protein, transforming growth factors (TGF- $\alpha$ or $-\beta$ ) and nuclear transcription factor-Kappa-B $(\mathrm{NF}-\mathrm{KB})$ resulting in activation of myofibroblast which started deposition of collagen and extracellular matrix components.

Reduction in collagen distribution between the gastric glands and in the submucosa of the caffeine treated and prophylactic rats (GIIIc, GIV) could be attributed to the antioxidant and anti-inflammatory effects of caffeine, where it suppresses inducible nitric oxide synthase (iNOS) and malondialdehyde (MDA) expressions with antagonizing their cytotoxic effect, by blocking the reactive oxygen radicals in human neutrophils, lipid peroxidation and exerts an anti-inflammatory effect via reducing proinflammatory cytokines and lowering levels of procollagen I, III and thus reduces collagen deposition ${ }^{[11,42]}$.

The ultrastructural changes observed in the gastric ulcer groups confirmed all findings depicted previously in the form of damaged parietal cells with dilated distorted intracellular canaliculi, many swollen electron-dense mitochondria, cytoplasmic vacuoles and shrunken irregular nuclei with dilated perinuclear cisternae. The distorted chief cell revealed dilated cisternae of rough endoplasmic reticulum, dilated Golgi complex with shrunken irregular nuclei when compared with the control group.

These degenerative changes could be explained based on oxidative stress induced by unlimited use of NSAIDs as it promotes progressive mitochondrial damage via changing the mitochondrial inner membrane composition, translocation of intra-mitochondrial protein (apoptosisinducing factor), damage mitochondrial DNA directly with ATP depletion and induces mitochondrial permeability of cytochrome $\mathrm{c}$ from mitochondrial intermembranous space into cytosol with the lowered activity of succinic dehydrogenase and diphosphopyridine nucleotide diaphorase leading to lipid peroxidation of biological membranes which increases its permeability to ions disrupting membrane structure ending with cell lysis ${ }^{[45,46]}$.

Dilatation of intracellular canaliculi of the parietal cell might be due to the re-arrangement of cytoskeleton and 
recruitment of $(\mathrm{H}+/ \mathrm{K}+$-ATPase $)$ rich tubulovesicles to the apical membrane causing expansion of the intracellular canaliculi into the inner core of the vacuolar spaces with loss of regular attachment of the luminal microvilli and activation of $\mathrm{H}+/ \mathrm{K}+-$ ATPase with subsequent gastric acid secretion following the loss of the inhibitory effect of prostaglandins on the oxyntic cells. Moreover, cytoplasmic vacuoles are due to the cellular ionic disturbance with retention of water and sodium leads to swelling of the parietal cell a condition called hydropic degeneration ${ }^{[36,37]}$.

The dilated rough endoplasmic reticulum and Golgi complex observed in peptic cells were explained by the theory of unfolded protein response, where retention of proteins takes place in rER because of impaired protein folding, leading to protein degradation, fragmentation, up-regulation of reactive oxygen species production and initiation of cellular apoptosis ${ }^{[47]}$.

Nuclear pyknosis detected in this work was likely a representation of cells undergoing apoptosis and atrophic degeneration secondary to increased reactive oxygen species (ROS) as a consequence of low-grade inflammatory disorder ${ }^{[37,48]}$.

The cytoprotective effects of caffeine with marked improvement in the histological structure and the ultrastructure of the gastric mucosa that was encountered in the caffeine treated and prophylactic groups (GIIIc, GIV) may be ascribed to the direct antioxidant and free radical scavenging activity and its anti-inflammatory properties that protect the gastric mucosa and inhibits the occurrence of gastric ulcers, even in the presence of aspirin which in turn prevent the occurrence of its complication ${ }^{[37,43]}$.

\section{CONCLUSION AND RECOMMENDATION}

In conclusion, the results of the present study showed that the oral administration of caffeine does not act as an irritant to the gastric mucosa and strongly indicated the gastro-protective and anti-ulcerogenic effects of caffeine in aspirin-induced gastric ulcer rat model. However, further clinical studies are necessary to determine whether it can be applied as preventive or therapeutic agents as shown in this preclinical study.

\section{CONFLICT OF INTERESTS}

There are no conflicts of interest.

\section{REFERENCES}

1. AL-Wajeeh NS, Hajrezaei M, Al-Henhena N, Kamran S, Bagheri E, Zahedifard M, Saremi K, Noor SM, Ali HM and Abdulla MA. The antiulcer effect of Cibotium barometz leaves in rats with experimentally induced acute gastric ulcer, Drug Design, Development and Therapy. 2017; 11: 995-1009.

2. Zatorski $\mathrm{H}$ : Introduction to Gastrointestinal Diseases. J.Fichna (ed.), Vol.2. 2017; Springer Nature, Switzerland.pp:7-20.
3. Enthoven WTM, Roelofs PD and Koes BW. Non-steroidal anti-inflammatory drugs for chronic low back pain. Journal of the American Medical Association. 2017; 317(22): 2327-2328.

4. Elgarawany GE, Ahmed FE, Tayel SI and Soliman SE. Effect of Garlic in Comparison with Misoprostol and Omeprazole on Aspirin Induced Peptic Ulcer in Male Albino Rats. Der Pharma Chemica. 2017; 9(6):68-74.

5. Wongrakpanich S, Wongrakpanich A, Melhado K and Rangaswami J. A Comprehensive Review of Non-Steroidal Anti-Inflammatory Drug Use in The Elderly. Aging and disease. 2018; 9 (1):143-150.

6. Abrahão SA, Pereira RGFA, Duarte SMS, Lima AR, Alvarenga DJ and Ferreira EB. Bioactive compounds and antioxidant activity of coffe (Coffea arabica L). Cienc e Agrotecnologia. 2010; 34 (2): 414-420.

7. Babova O, Occhipinti A and Maffei ME. Chemical partitioning and antioxidant capacity of green coffee (Coffea arabica and Coffea canephora) of different geographical origin. Phytochemistry. 2016; 123: 33-39.

8. 8. DePaula J and Farah A. Caffeine Consumption through Coffee: Content in the Beverage, Metabolism, Health Benefits and Risks Beverages. 2019; 5(37):3-50.

9. Lima JP and Farah A. Caffeine and minor methylxanthines in coffee. In Coffee: Consumption and Health Implications; Farah A (Ed.). 2019; Royal Society of Chemistry, London.pp: 543-564.

10. Kitzberger CSG, Scholz MB and Benassi MT. Bioactive compounds content in roasted coffee from traditional and modern Coffea arabica cultivars grown under the same edapho-climatic conditions. Food Res.Int. 2014; 61: 61-66.

11. Pellizzon CH, de Souza MO, Sérgio Gushiken LF and Beserra FP. Evaluation of the Gastroprotective and Antioxidant Effects of Caffeine and Caffeic Acid on Ethanol-Induced Gastric Ulcer. JSM Hepat. 2017; 2 (1): 1008.

12. Khushtar M, Kumar V, Javed K and Bhandari U. Protective Effect of Ginger oil on Aspirin and Pylorus Ligation-Induced Gastric Ulcer Model in Rats. Indian J Pharm Sci. 2009; 71(5): 554-558.

13. Dawud FA, Mabrouk MA, Mohammed A and Umar IA. Effect of Vitamins C \& E on Aspirin Induced Gastric Mucosal Damage and Oxidative Stress.Current Research Journal of Biological Sciences. 2014; 6 (1): 36-41.

14. Wang Z, Hasegawa J, Wang X, Matsuda A, Tokuda T, Miura N and Watanabe T. Protective Effects of Ginger against Aspirin-Induced Gastric Ulcers in Rats. Yonago Acta Med. 2011; 54(1):11-9. 
15. Hadda TB, ELSawy NAM, Header EAM, Mabkhot YN and Mubarak MS. Effect of garlic and cabbage on the healing of gastric ulcer in experimental rats. Medicinal Chemistry Research. 2014; 23: 5110-5119.

16. Bancroft JD and Layton C. The hematoxylin and eosin, connective mesenchymal tissues with their stains In: Suvarna SK, Layton $\mathrm{C}$ and Bancroft JD (eds). Bancroft's Theory and practice of histological techniques. ( $7^{\text {th }}$ edition). 2013; Churchill Livingstone, Philadelphia. pp: 173-212 and 215-238.

17. Hayat MA: Principles and Techniques of Electron Microscopy: Biological Applications. $4^{\text {th }}$ ed. 2000; Cambridge university press, Cambridge, United Kingdom. pp 85-138.

18. Emsley R, Dunn G, White IR.Mediation and moderation of treatment effects in randomized controlled trials of complex interventions. Stat Methods Med Res. 2010; 19(3): 237-270

19. Kim SY, Min C, Oh DJ and Choi HG. Reciprocal association between depression and peptic ulcers: Two longitudinal follow-up studies using a national sample cohort. Scientific Reports. 2020; 10 (1749):1-8.

20. Zalecki M. Gastric ulcer induced changes in substance $\mathrm{P}$ and $\mathrm{Nk} 1, \mathrm{Nk} 2, \mathrm{Nk} 3$ receptors expression in different stomach localizations with regard to the intrinsic neuronal system. Histochemistry and cell biology. 2019; 151(1):29-42.

21. Welsh EJ, Bara A, Barley E and Cates CJ. Caffeine for asthma. Cochrane Database Syst Rev. 2010; (1):CD001112.

22. Temple JL, Bernard C, Lipshultz SE, Czachor JD, Westphal JA and Mestre MA. The Safety of Ingested Caffeine: A Comprehensive Review. Front Psychiatry. 2017; 8(80):1-19.

23. Sengupta P. The Laboratory Rat: Relating Its Age With Human's. Int $J$ Prev Med. 2013; 4(6): 624-630.

24. Wilson C. The clinical toxicology of caffeine: A review and case study. Toxicol Rep. 2018; 5: 1140-1152.

25. Katherine AS, Niamh MM and Steve RB. Hypothalamic regulation of appetite. Exp Rev Endocrinol Metab.2008; 3(5): 577-592.

26. Adefisayoa MA, Akomolafeb RO, Stephen O, Akinsomisoyeb SO, Alabib QK, Ogundiped OL, Omoleb GJ and Olamilosoyeb KP. Gastro-protective effect of methanol extract of Vernonia amygdalina (del.) leaf on aspirin-induced gastric ulcer in Wistar rats. Toxicology Reports. 2017; 4: 625-633.
27. Mazzafera P and Silvarolla MB. Caffeine content variation in single green Arabica coffee seeds. Seed Sci. Res. 2010; 2010 (20):163-167.

28. Suheryani I, Li Y, Dai R, Liu X, Anwer S, Juan $\mathrm{S}$ and Deng Y. Gastroprotective effects of Dregea Sinensis Hemsl. (Daibaijie) against aspirininduced gastric ulcers in rats. Int. J. Pharmacol. 2017; 13 (8):1047-1054.

29. El-Azab NE, Mansy AE, El-Mahalaway AM and Sabry D. Comparative study of the therapeutic effect of pomegranate alone or in combination with bone marrow mesenchymal stem cells on experimentally induced gastric ulcer in adult male rats: A histological and immunohistochemical study. EJH. 2018; 41(2):150-166.

30. Köroğlu ÖA, MacFarlane PM, Balan KV, Zenebe WJ, Jafri A, Martin RJ and Prabha K. AntiInflammatory Effect of Caffeine is Associated with Improved Lung Function after LPS-induced Amnionitis. Neonatology. 2014; 106 (3): 235-240.

31. Siddiqui F, Ahmed M, Abbasi S, Avula A, Siddiqui AH, Philipose J, Khan HM, Khan TM, Deeb L and Chalhoub M. Gastrointestinal Bleeding in Patients With Acute Respiratory Distress Syndrome: A National Database Analysis. J Clin Med Res. 2019; 11(1):42-48

32. Revathi G, Elavarasi $\mathrm{S}$ and Saravanan $\mathrm{K}$. Protective Effect of Daucus Carota (Carrot) and Raphanus Sativus (Radish) on Aspirin Induced Gastric Ulcer In Albino Rat Models. IJSART. 2017; 3 (9): 2395-1052.

33. Mahmoud YI and Abd El-Ghaffar EA. Spirulina ameliorates aspirin-induced gastric ulcer in albino mice by alleviating oxidative stress and inflammation. Biomedicine \& Pharmacotherapy. 2019; 109: 314-321.

34. Cryer B and Mahaffey KW.Gastrointestinal ulcers, role of aspirin, and clinical outcomes: pathobiology, diagnosis, and treatment.Journal of Multidisciplinary Healthcare.2014; 7:137-146.

35. Rubin R and Strayer DS. Rubin's Pathology: Clinicopathologic Foundations of Medicine. $6^{\text {th }}$ edition. 2012; Lippincott Williams \& Wilkins. Philadelphia.pp:14-15.

36. Bjarnason I, Scarpignato C, Holmgren E, Olszewski M, Rainsford KD and Lanas A. Mechanisms of Damage to the Gastrointestinal Tract From Nonsteroidal Anti-Inflammatory Drugs. Jgastro. 2018; 154(3):500-514.

37. Radwan DM, Ebrahim NA, Farag EA and Sofi MA. Histological Study on the Possible Protective Effect of Co-enzyme Q10, Evening Primrose and Esomeprazole on Indomethacin Induced Gastric Ulcer in Adult Male Albino Rats. Nat Sci. 2019; 17(12):220-240. 
38. Ezemagu UK, Akunna GG, Egwu OA, Uzomba GC and Nwite KN. Comparing Ficus vogelii leaf extract and omeprazole as therapy and prophylaxis for aspirin-induced gastric ulcer in Wistar rat. Biomedical Research. 2019; 30 (5): 697-703.

39. Abd El-Salam S, Faruk EM and Fouad H. Evaluation of Therapeutic Potentials of $\alpha$-Lipoic Acid Versus Stem Cells-Derived Microvesicles Against Experimentally-Induced Gastric Ulcer in Adult Male Albino Rats (Light and Electron microscopic study). Egyptian Journal of Histology. 2019;42(4):915-927.

40. Elwan WM and Ibrahim MAA. Effect of tartrazine on gastric mucosa and the possible role of recovery with or without riboflavin in the adult male albino rat. EJH. 2019; 42 (2): 297-311.

41. Arisha SM. Effect of saffron extract on ethanol-induced gastric ulcer in albino rats: Histological, ultrastructure and immunohistochemical studies. Journal of Bioscience and applied research. 2017; 3(3):226-240.

42. Castro ACCM, Oda FB, Almeida-Cincotto MGJ, Davanço MG, Chiari-Andréob BG, Cicarelli RMB, Peccinini RG, Zocolo GJ, Ribeiro PRV, Corrêa M, AIsaac VLB and Santos AG. Green coffee seed residue: A sustainable source of antioxidant compounds. Food Chemistry. 2018; 246: 48-57.
43. Ezemagu UK, Akunna GG, Egwu OA, Uzomba GC and Nwite KN. Comparing Ficus vogelii leaf extract and omeprazole as therapy andprophylaxis for aspirin-induced gastric ulcer in wistar rat. Biomedical Research. 2019; 30 (5): 697-703.

44. De Mejia EG and Ramirez-Mares MV. Impact of caffeine and coffee on our health, Trends Endocrinol. Metab. 2014; 25(10):489-492.

45. Selim MM, Elshal EB and Abd Elwahab AH. Effect of Ellagic Acid on Gastric Mucosa of Experimentally Induced Gastric Ulcer: Histological and Immunohistochemical Study. Ejpmr. 2016; 3 (12): 658-667.

46. Sabry SA. Histological and Ultrastructural Studies on the Effect of Amoxicillin on the Stomach of Mouse Fetuses. The Egyptian Journal of Hospital Medicine. 2017; 67 (1): 366-376.

47. Kengkoom K, Tirawanchai N, Angkhasirisap W and Ampawong S. Omeprazole preserves the RER in chief cells and enhances re-epithelialization of parietal cells with SOD and AQP 4 upregulation in ethanol-induced gastritis rats. Exp Ther Med. 2017; 14 (6): 5871-5880.

48. Tao Y, Xie S, Xu F, Liu A, Wang Y, Chen D, Pan Y, Huang L, Peng D, Wang X and Yuan Z. Ochratoxin A. Toxicity, oxidative stress and metabolism, Food Chem. Toxicol. 2018; 112:320-331. 


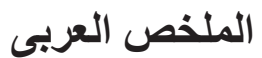

\section{تأثيرالكافيين على التركيب النسيجي لبطانة المعدة السليمة والمصابة بالقرحة المستحثة

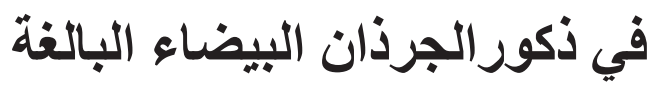

أسماء حسن عبد الحميد، منى عبد الرحمن سالم، شادية محمد محمود، منى محمد عبد الجليل قسم الهسنولوجيا ـ كلية الطب (بنات)- جامعة الازهر

مقدمة: تعتبر قرحة المعدة مشكلة صحية خطيرة تهم العالم بأسره. وقد تأكد عالميا دور الكافيين كعنصر غذائي آمن نتيجة لمحتو اه العالي من مضادات فئر الأكسدة. الهدف من البحث: تقييم الدور الوقائي للكافيين على الغشاء المخاطي في المعدة السليمة وقرحة المعدة المستحثة بالأسبرين في ذكور الجرذان البيضاء البالغة. المواد والطرق: تم تقسيم اثنين و أربعين جرذا من الذكور البيضاء البالغة إلى البـ اربعة مجمو عات: المجمو عة الأولى: المجمو عة الضابطة. المجموعة الثانية: مجموعة الكافيين ، و التى أعطيت الكافيين بجر عة ( . . امجم/كجم يوميا) عن طريق الفم بواسطة أنبوب معدي. المجمو عة الثالثة : تم إعطاء الجرذان الصائمة محلول الأسبرين ( · . ب مجم/كجم يوميا) عن طريق الفم لمدة خمسة ايام

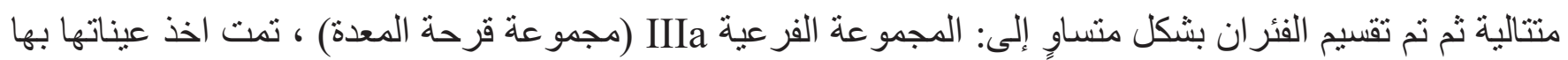
بعد ست ساعات من آخر جر عة الأسبرين

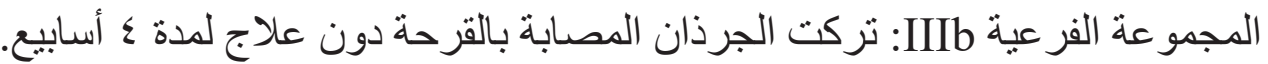
المجمو عة الفرعية IIIc مجمو عة قرحة المعدة المعالجة بالكافيين لمدة ؟ أسابيع.

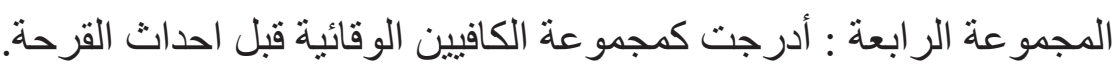

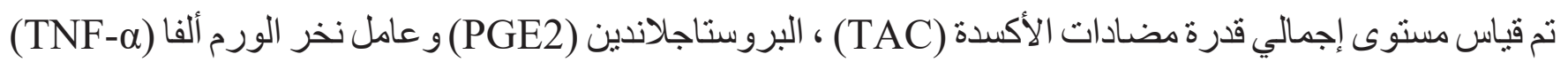
في السيرم. كما تم تحضير عينات المعدة لفحصها نسيجيا بالميكرسكوب الضوفئي والالكتروني. كما تم اجر اء التحليل الاحصائي لكافة النتائج. النتائج: أظهر الفحص المجهري لمجموعة قرحة المعدة تآكلا عميقا ، و تلفا بالخلايا الجدارية و الرئيسية مع فجوات

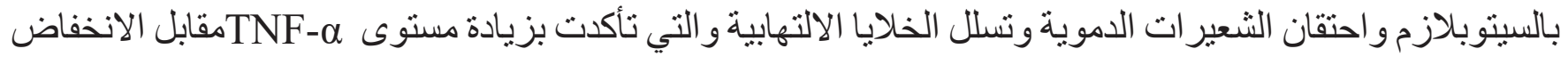
الكبير في كل من مستويات TAC و PGE2 وقد دعم ذللك انخفاض كبير في تفاعل PAS بع زيادة كبيرة في النسبة المئوية من مساحة ألياف الكو لاجين. وقد أكد التركيب النسيجي الدقيق هذه التشو هات. بينما أظهرت المجمو عات التهات الوقائية

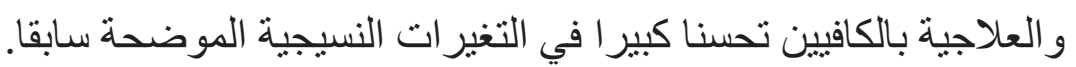
خلاصة البحث: تم تأكيد تأثنير الكافيين الوقائي على الغشاء المخاء العاطي للمعدة. كما انه قد خفض من تلف الغشاء المخاطي الناجم عن الأسبرين في ذكور الجرذان البيضاء البالغة ويعزي ذلك الى محتو اه العالي من مضادات الأكسدة. 